\title{
EXPERIÊNCIA E GENTE NAS IMAGENS DA CIDADE
}

\author{
Urpi Montoya Uriarte ${ }^{1}$
}

Iniciarei este artigo partilhando um material gráfico produzido por duas turmas da disciplina Antropologia Urbana (2013.1 e 2015.1) que ministro para o curso de Ciências Sociais da Universidade Federal da Bahia (UFBA) ${ }^{2}$. No primeiro encontro com os alunos, solicito-lhes que, em 20 minutos, desenhem num pedaço de papel o que é a cidade. $\mathrm{O}$ exercício os pega de surpresa e, com frequência, os comentários são: "isso é muito difícil!”, “não sei desenhar, professora!”, “é para desenhar que cidade?”, "não dá para fazer isso em 20 minutos!". Com efeito, trata-se de um exercício bastante complexo. Primeiro, porque se pede que os alunos tenham uma imagem mental da cidade, quando muitos não a têm. Segundo, porque os alunos de ciências sociais não são preparados ao longo do curso para transformar técnica e artisticamente uma imagem visual numa imagem material. Por último, porque o enunciado é pouco específico. De fato, a simplificação da demanda é intencional, esperando que o aluno desenhe a primeira imagem da cidade que lhe vem à mente, supondo que, por ser a primeira, ela seria a mais próxima de sua efetiva percepção dela.

Na disciplina, os desenhos me servem para nortear a discussão inicial sobre o conceito de cidade. Com efeito, os desenhos mostram, ora espaços centrais, comércio e serviços, ora meios de comunicação, vias de trânsito, bairros etc. Nestas páginas, eles me servem de material para refletir sobre o quê as imagens de cidade priorizam e por quê. Assim, na primeira parte do artigo me interessa interpretar o quê esses desenhos estão falando sobre a cidade contemporânea. Vale ressaltar que não apresentarei aqui a totalidade dos desenhos, nem explorarei extensivamente todos os significados possíveis deles. Por razões de espaço, comprimi as minhas interpretações em seis blocos, reproduzindo apenas alguns desenhos em cada um.

Mas, antes de apresentar os desenhos e o que eu penso das imagens da cidade que eles refletem, é necessário, primeiro, definir o que é uma imagem. Como muitas outras categorias, a de imagem tem também vários significados ${ }^{3}$. Considerarei aqui a

\footnotetext{
${ }^{1}$ Universidade Federal da Bahia, Brasil.

${ }^{2}$ Preferi omitir os nomes dos autores dos desenhos. Ao longo do artigo, referir-me-ei a eles e elas como "autores", "desenhistas" ou "alunos".

${ }^{3}$ Etimologicamente, a palavra provém do latim imago, que designava a máscara mortuária usada nos funerais na Antiguidade romana. A máscara era uma imagem cuja função consistia em manter viva a
} 
imagem como uma representação, ou seja, como um "objeto segundo com relação a um outro que ela representaria" (Joly, 1994: 4). As imagens são de diversos tipos: fixas (fotografia), animadas (cenas), verbais (metáforas), visuais (pintura), "naturais" (paisagens) e imateriais ou mentais. Estas últimas, que não podem ser captadas mediante os sentidos, são aquelas representações imediatas que, apesar de não termos consciência de sua origem, são bastante nítidas, a ponto de termos a impressão de "vêlas" em nossas mentes. Como essas imagens são produzidas? A partir de quais elementos? Responderei estas perguntas na segunda parte do artigo, contrapondo os desenhos de cidade aos desenhos dos percursos cotidianos efetuados por cada aluno. Vejamos, portanto, primeiro, os desenhos de cidade.

\section{Imagens da cidade}

A imagem que os indivíduos têm da cidade não é unívoca, clara, consolidada ou permanente, o que faz com que chegar a ela seja uma tarefa árdua. É preciso cruzar informações de diversos tipos, tal qual o fez Kevin Lynch em seu clássico A imagem da cidade (1997). Esse autor conseguiu chegar à imagem da cidade que os habitantes de Boston (Massachusetts), Jersey City (New Jersey) e Los Angeles (Califórnia) tinham mediante relatos, entrevistas, desenhos, percursos acompanhados etc. Ou seja, através de um material bastante diversificado e, além disso, numericamente significativo. Dessa forma, ele conseguiu detectar as "imagens públicas" dessas três cidades, isto é, "as imagens mentais comuns a vastos contingentes de habitantes de uma cidade" (Lynch, 1997: 8). Seu objetivo era coletar material sobre a "imaginabilidade" dessas cidades para tirar conclusões que servissem diretamente aos profissionais do design urbano, aos projetistas de cidades. A sua era uma meta bastante ambiciosa.

Inicio esta seção colocando as características do trabalho de Lynch para ressaltar o caráter despretensioso da forma e do material com o qual irei trabalhar neste artigo. Trata-se só de desenhos (sem entrevistas, depoimentos etc.), que não fazem parte de uma pesquisa em curso cujo tema central seja detectar a imagem que os soteropolitanos têm de Salvador. O material é numericamente modesto, pois oriundo de um exercício

memória dos mortos mediante uma representação visual. Por outro lado, há uma relação entre a palavra imagem e a raiz imitare, que sugere a ideia de semelhança. A imagem seria algo que se assemelha a outra coisa; que lembraria a coisa pela analogia de forma, cor, proporção. A semelhança entre a coisa e a imagem foi interpretada por alguns pensadores como sendo uma enganação, uma ilusão, uma falsidade, tendo, portanto, de nos cuidarmos das imagens. 
cujos propósitos eram outros, razão pela qual não pretendo generalizar nenhuma das imagens aqui apresentadas e discutidas. Por último, meu objetivo é igualmente discreto: trata-se de refletir sobre os aspectos que as imagens da cidade reunidas enfatizam e indagar sobre suas possíveis razões mediante o diálogo com diversos autores.

Num primeiro bloco agrupei três desenhos que mostram uma mesma imagem: a cidade compartimentalizada. Nesses desenhos de cidade, tudo tem seu lugar separado: as casas de um lado, os prédios de outro, os serviços concentrados em torno das avenidas. Entre os espaços residenciais aparece um espaço intermediário - as praças -, porém, sempre desocupado. Há vias que conectam as partes, mas estão surpreendentemente vazias. Nessas imagens, não há pessoas, não há gente, não há alteridade. No terceiro desenho aparecem algumas pessoas, contudo, mais parecendo robôs que vão satisfazer suas necessidades de abastecimento, saúde, alimentação e educação, em caixas - de dimensões iguais - que se estendem ao longo de uma via reta.

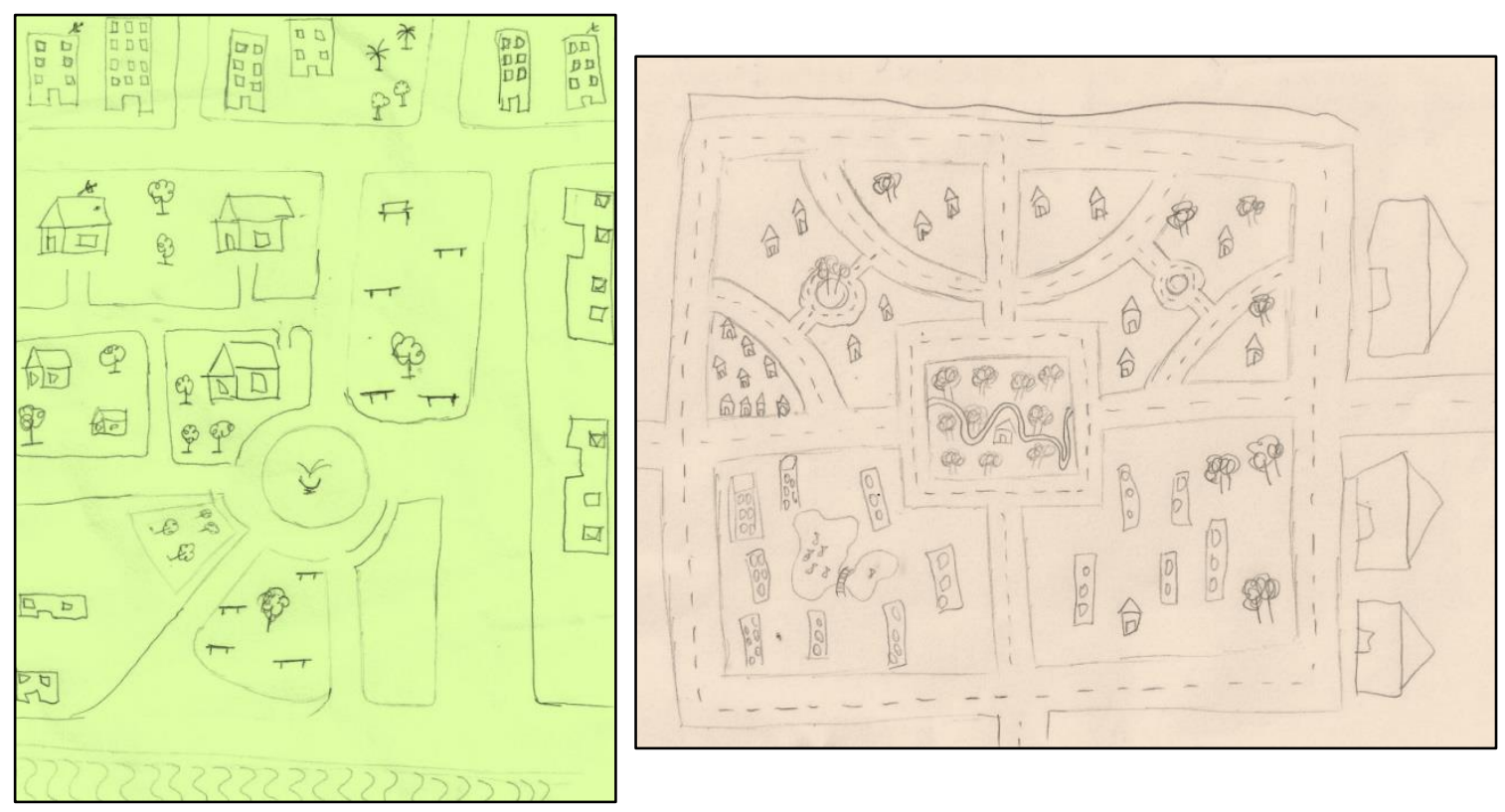




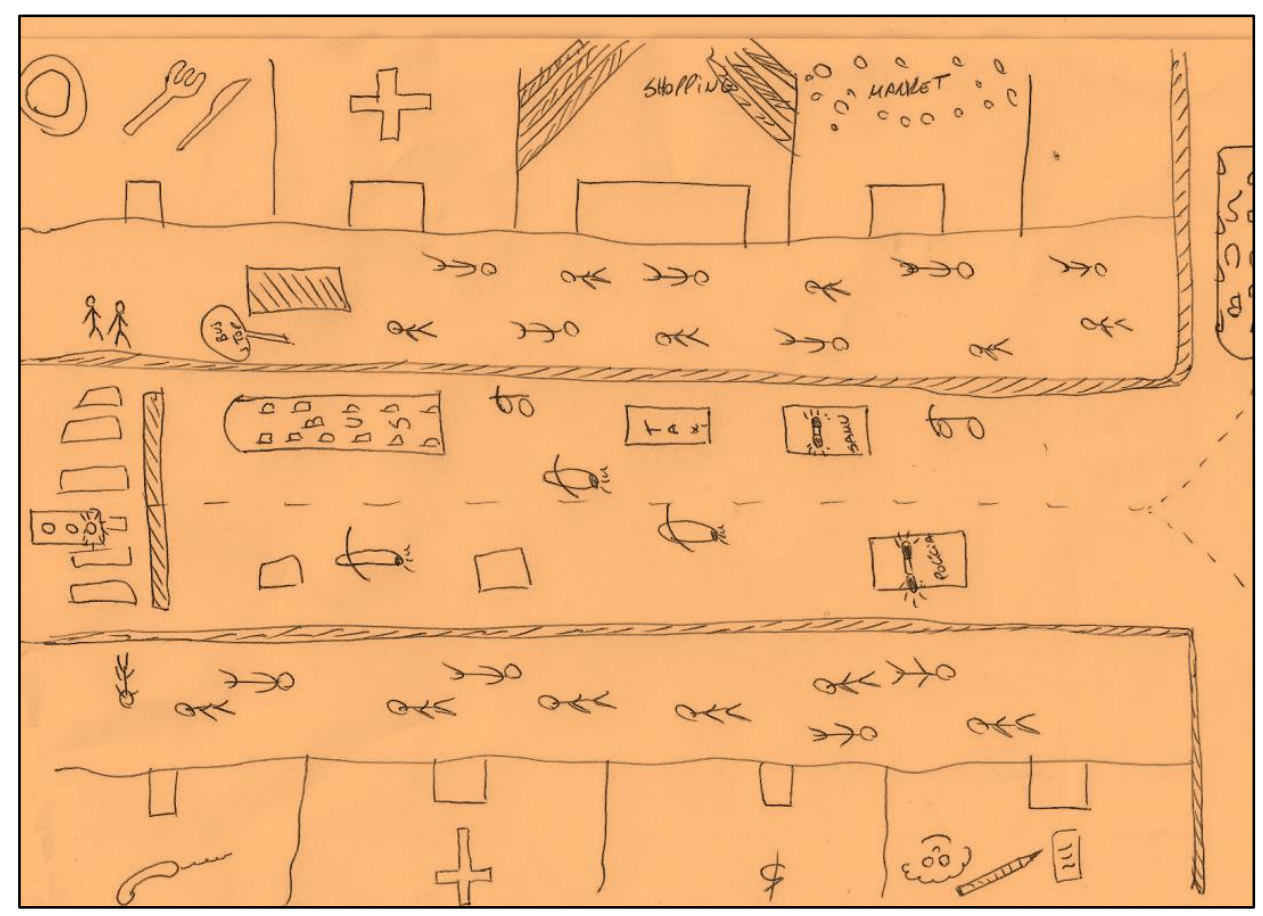

Estas imagens correspondem claramente às cidades modernas, industriais, contrastando, portanto, com as cidades pré-industriais, cuja característica principal era a de ser um espaço concentrado de usos mistos. Nelas, moradia e comércio conviviam lado a lado, quando não no mesmo edifício; classes socialmente opostas evidenciavam suas contradições nas roupas usadas ou nas maneiras empregadas, porém, não espacializavam essas diferenças ${ }^{4}$. O desenvolvimento do capitalismo foi, paulatinamente, fragmentando o que era uma unidade, separando o que era próximo, excluindo o que alguma vez formou parte de um todo. $\mathrm{O}$ urbanismo funcionalista das primeiras décadas do século $\mathrm{XX}$, em nome do pragmatismo e da racionalidade, sacralizou a fragmentação, a separação e a compartimentalização da cidade.

Le Corbusier foi um arquiteto fundamental na construção e legitimação da cidade compartimentalizada. Para se adequar à nova vida industrial ("século da máquina") e comercial intensa, ele propôs dividir a cidade em quatro tipos de espaço: espaços para morar, se divertir, trabalhar e circular (Le Corbusier, 1962). Suas ideias,

\footnotetext{
${ }^{4}$ Referindo-se aos burgos medievais e às cidades coloniais brasileiras, Raquel Rolnik (1988: 45-46) escreveu que eram "espaços polivalentes do ponto de vista funcional e misturados do ponto de vista social. Como no burgo medieval, na cidade colonial não existem regiões/trabalho e regiões/moradia, praças da riqueza, praças da miséria. Isto, evidentemente, não quer dizer que não existam nestas cidades diferenças de classe ou posição social (...). Estas distâncias, assim como as distâncias entre senhores e escravos nas cidades brasileiras, não eram físicas".
} 
sistematizadas e popularizadas na Carta de Atenas, de $1933^{5}$, se propagaram por todos os continentes, remodelando cidades dos mais diversos tipos. $\mathrm{O}$ urbanismo funcionalista acreditava que, com usos previamente estabelecidos, os espaços se tornariam menos "caóticos", mais racionais, portanto, mais produtivos. A ordem, entendida como ausência de conflitos, supôs a homogeneidade como pré-condição indispensável. Assim, chegou-se à separação e à compartimentalização da cidade.

Não seria correto criticar a atual compartimentalização propondo simplesmente uma volta à antiga diversidade e justaposição de usos. $\mathrm{O}$ que precisamos é rever com urgência o que entendemos por ordem e, nessa tarefa, Richard Sennett é um autor absolutamente necessário. Em The uses of disorder (1970) ele demonstra que a ordem não significa ausência de conflito, mas a negociação dele. $O$ conflito existe e não pode ser negado, precisa ser negociado, o que supõe que as diferenças efetivamente se encontrem no espaço. $\mathrm{O}$ encontro foi precisamente o propósito histórico do espaço público das cidades, que necessariamente supõe ambiguidade, incerteza e surpresa. Em suas palavras,

o que deve emergir na vida urbana é a ocorrência de relações sociais e, especialmente, de relações envolvendo conflito social, mediante encontros face-aface. Experimentar a fricção das diferenças e conflitos torna os homens pessoalmente conscientes do contexto ao redor de suas vidas; é necessário que os homens reconheçam o conflito, e não que tentem purificá-lo mediante o mito da solidariedade para poder sobreviver. $\mathrm{O}$ fórum social que encoraja a mudança para a maturidade depende primeiramente da certeza de que não há como escapar das situações de confronto e conflito. A cidade é o único espaço que pode oferecer a reunião para esses encontros (Sennett, 1970: 139, tradução da autora).

\footnotetext{
${ }^{5}$ Como nos recorda Sérgio Abrahão (2008: 63), “a Ville Radieuse foi proposta por Le Corbusier em 1930, durante o III CIAM, e as principais ideias nelas estampadas foram debatidas em 1933, durante o IV CIAM, e posteriormente sistematizadas e publicadas em um documento coletivo conhecido internacionalmente como a Carta de Atenas".
} 
Um segundo bloco de desenhos mostra precisamente a imagem da cidade associada ao espaço público, mais especificamente, à centralidade da praça.
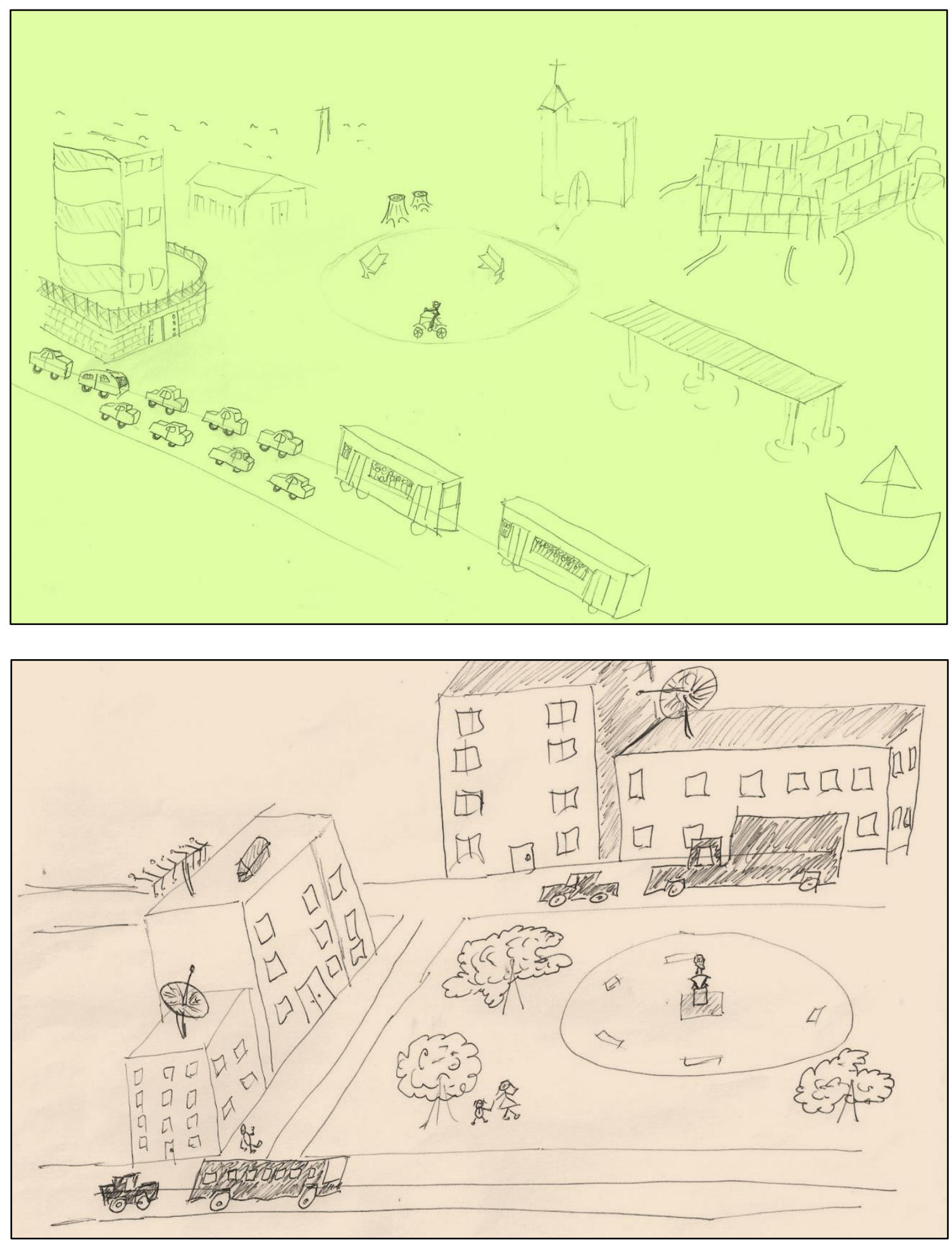
Em O declínio do homem público, Sennett (1988: 58) definiu a cidade como "um assentamento humano no qual estranhos irão provavelmente se encontrar". Dentre os espaços da cidade que foram o palco desses encontros, a rua e a praça ocupam um lugar privilegiado. Segundo este autor, até o século XVIII o encontro nesses espaços não era uma opção, mas antes uma necessidade que emergia do convívio estreito em espaços limitados (pelas muralhas, pela dificuldade de se locomover). A diversidade convivia e se encontrava nos espaços públicos graças a um acordo implícito fundamental: agir a certa distância do Eu. Disfarces (roupas), máscaras (todos pintavam o rosto) e discursos (negação arbitrária das marcas de estratificação) serviam para ocultar o sujeito que fazia o gesto ou usava o símbolo: importavam estes e não quem os fazia.

Se Sennett estiver certo em sua análise histórica da convivência urbana na Europa do século XVIII, a alteridade não era negada, mas era ocultada na cidade, como parte de um princípio teatral para que ela pudesse sobreviver nela. Contudo, o avanço do capitalismo alterou as regras desse jogo. A partir do século XIX, as muralhas externas foram derrubadas, os bondes possibilitaram a expansão da cidade e, depois, o automóvel promoveu seu crescimento ilimitado. O convívio estreito deixou de ser uma necessidade e o convívio das diferenças - com suas práticas teatrais e seu código de máscaras - foi se extinguindo. Com o afastamento físico entre os diferentes, o domínio público passou a ser moralmente inferior e o encontro com o Outro se tornou uma aberração perigosa. Alteridade, desigualdade e perigo se tornaram sinônimos. Praças e ruas deixaram de ser concebidas como espaços para ficar e se transformaram em espaços de passagem, ao mesmo tempo em que os muros foram se erguendo dentro da própria cidade.

O que estes desenhos nos mostram é precisamente a praça esvaziada de sua tradicional função de palco de encontros. São praças sem gente. Deduzo que as pessoas estão nos ônibus ou nos prédios, muitos dos quais estão devidamente cercados, conforme se pode observar no segundo desenho. O curioso é que, em ambas as imagens, as poucas pessoas que usam o espaço público são crianças. Talvez João do Rio (2008: 44) tivesse razão ao afirmar que, "instintivamente, quando a criança começa a engatinhar, só tem um desejo: ir para a rua!". Depois, como acabamos de ver, o "instinto" é completamente reprimido ou extinto. 
Um terceiro bloco de desenhos revela o que chamo de imagens sofridas de cidade. O primeiro desenho mostra uma cidade apertada no cimento (não há espaço entre os prédios), o que deixa o sol descontente, uma árvore sem folhas, o céu alterado e a grande maioria dos habitantes sumidos no cimento e no descontentamento. O desenho mostra uma cidade monocromática, de um ritmo único, uma cidade que, assim como os prédios sem janelas, não apresenta saídas.

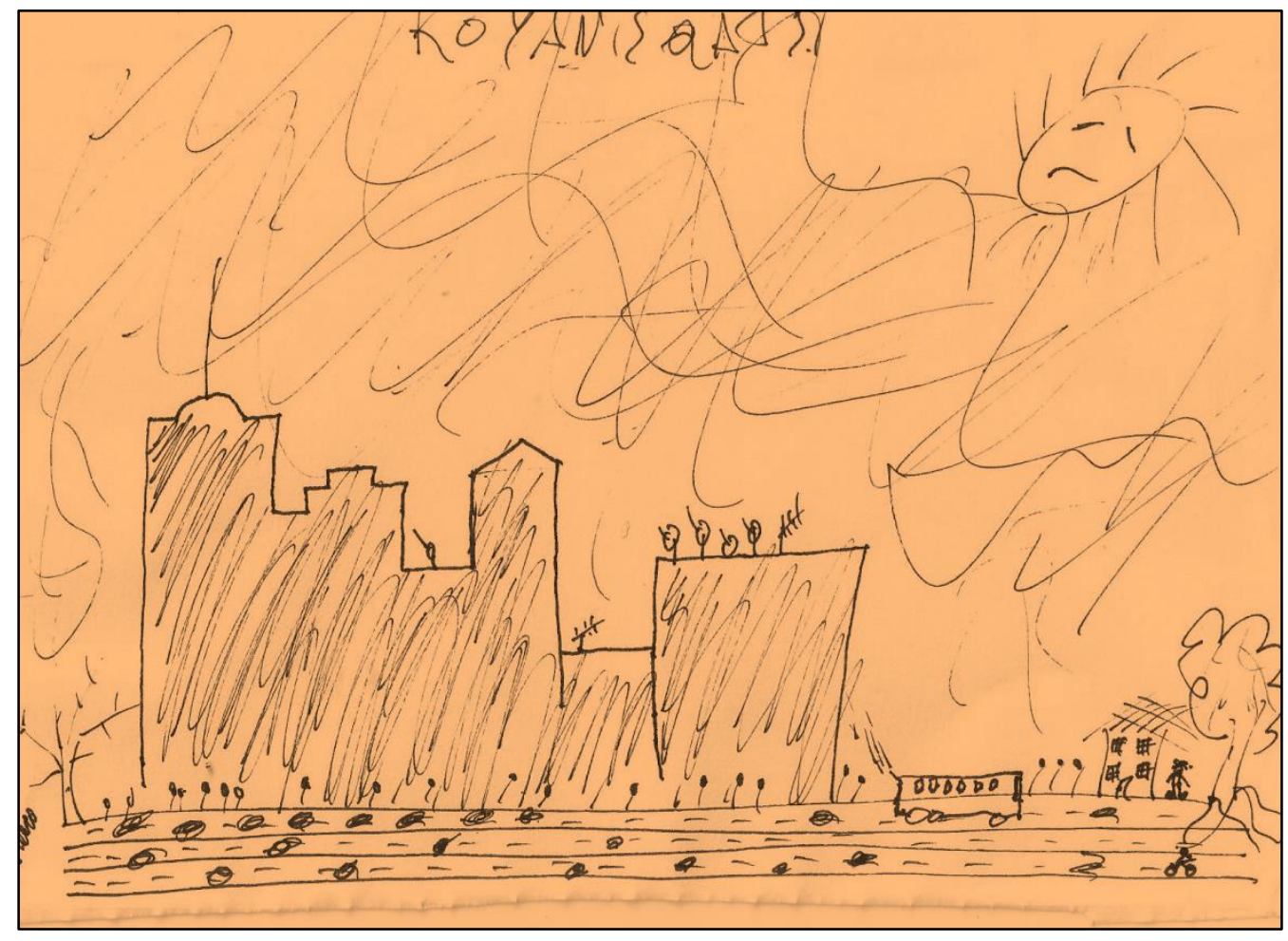

Para além do descontentamento, o segundo desenho deste bloco fala de outro sentimento: o medo e a necessidade ou de iluminação ou de paredes e de arames. $\mathrm{O}$ indivíduo, só, sobrevive ali onde há luz (embaixo do poste e não no ponto de ônibus) ou ali onde há aparelhos de proteção (a casa). 


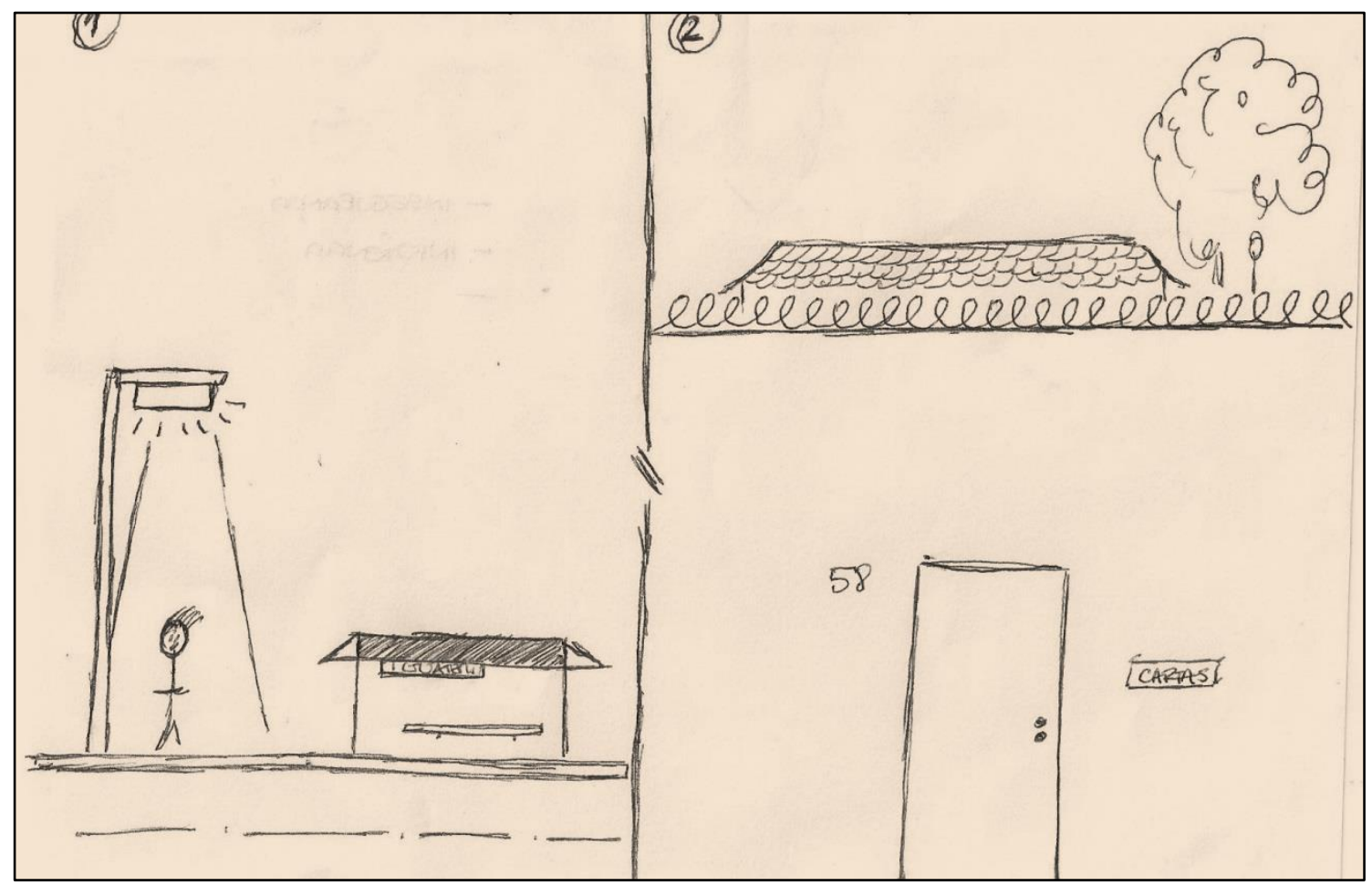

A sensação de insegurança é, na opinião de Manuel Castells (apud Bauman, 2009), inerente à sociedade moderna e ao individualismo que está em sua base: "suspeitamos dos outros e de suas intenções, nos recusamos a confiar (ou não conseguimos fazê-lo) na constância e na regularidade da solidariedade humana" (Bauman, 2009: 16). Para Zygmunt Bauman, o medo do desconhecido seria intrínseco à vida urbana: a presença dos estrangeiros - do Outro - nas cidades é "uma fonte inexaurível de ansiedade e agressividade latente - e muitas vezes manifesta" (idem, p. 36). A questão é como se enfrenta essa ansiedade latente. Retomando visivelmente a argumentação de Sennett exposta nos blocos anteriores, Bauman nos diz que grande parte do medo urbano atual emerge da incapacidade de conviver com o Outro:

Como as pessoas esqueceram ou negligenciaram o aprendizado das capacidades necessárias para conviver com a diferença, não é surpreendente que elas experimentem uma crescente sensação de horror diante da ideia de se encontrar frente a frente com estrangeiros. Estes tendem a parecer cada vez mais assustadores, porque cada vez mais alheios, estranhos e incompreensíveis (Bauman, 2009: 46).

O medo e o pânico dominam a imagem da cidade quando a alteridade passa a ser sinônimo de perigo, quando um contingente cada vez maior de indivíduos (as "novas classes perigosas") é percebido como definitivamente inapto para ser reintegrado socialmente, quando a autossegregação e a segregação dos Outros são assumidas como 
as melhores formas de habitar uma cidade. Muros cada vez mais altos, cercas elétricas e iluminação se fazem cada vez mais necessárias para sentir um mínimo de segurança.

O terceiro desenho deste bloco talvez seja o mais dramático. A cidade não passa de um agrupamento de vias para o trânsito.

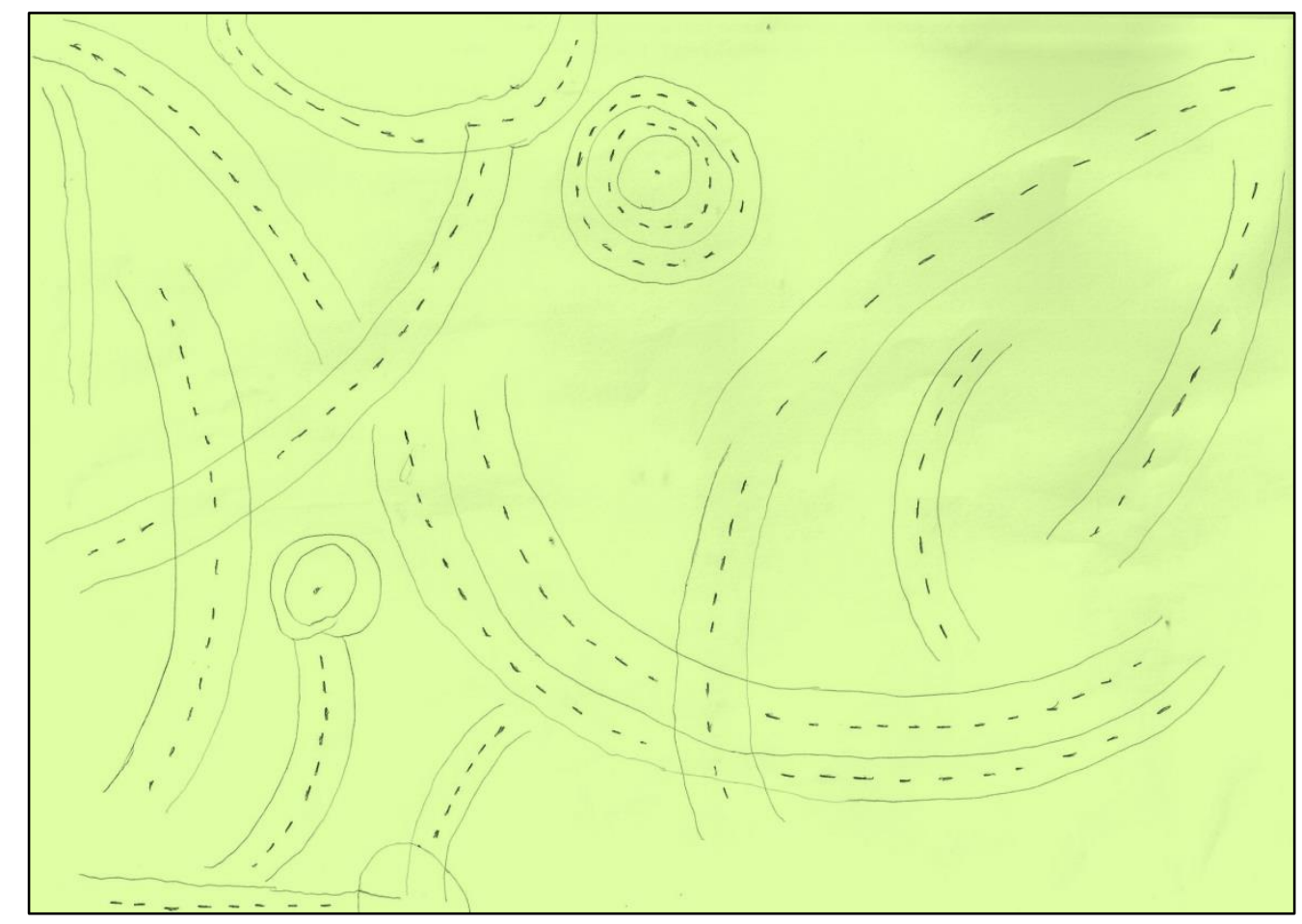

Este desenho mostra o quanto a cidade, entendida como "máquina para circular" (Le Corbusier, 1962), foi implementada e interiorizada. Demonstra dramaticamente o quanto a rua deixou de ser para e das pessoas e passou a ser dos carros. A velha rua estreita, tortuosa, formada de esquinas e escondendo cantos e recantos cedeu lugar à via expressa, para máquinas cada vez mais velozes. Interiorizaram-se as ideias funcionalistas, tão bem descritas por Jane Jacobs, segundo as quais

\footnotetext{
a rua é um péssimo contexto para os seres humanos; as casas deveriam dar as costas à rua e a frente a espaços internos e verdes, protegidos (...). Deve separar-se o comércio das residências e espaços verdes (...), a presença de muitas pessoas nas proximidades é um mal e uma boa urbanização tem de procurar em todo momento criar nem que seja a sensação de isolamento e intimidade (Jacobs, 1973: 24, tradução da autora).
} 
Na década de 1950, Jacobs alçou sua voz contra a matança das ruas e, com elas, das cidades norte-americanas. Era preciso, a seu ver, recuperar as ruas e sua diversidade essencial, única garantia de sua vitalidade e segurança. Propôs que as ruas deviam abrigar, além de moradias, um comércio diversificado, pois ele garantiria o uso delas e a segurança nelas. Recomendou não ser contra a densidade, ser a favor dos quarteirões curtos, das esquinas (e cruzamentos), dos edifícios variados em idades, da heterogeneidade social de seus moradores.

Hoje, o arquiteto dinamarquês Jan Ghel (2013) retoma as propostas de Jacobs. As áreas devem ser mistas, diz ele, combinando moradia, lojas, restaurantes, monumentos e funções públicas. Os edifícios não podem ser considerados obras de arte individuais, pois eles fazem parte de um todo ao qual devem se adequar - a cidade -, cuja função social primordial é a do encontro. Portanto, os edifícios devem refletir e promover o uso misto, não podendo ser autossuficientes. O pedestre deve ser o sujeito da cidade é não o carro. Além de um bom sistema público de transporte, as vias de pedestres e de bicicletas devem ser priorizadas, pois são elas que permitem que as pessoas fiquem, observem, se cumprimentem, conversem, façam amizades. A escala de qualquer pensamento e planejamento da cidade deve ser a escala humana: do pequeno, do lento, do próximo.

Ghel nos mostra através de inúmeras fotografias o quanto a vida na cidade muda quando os paradigmas do urbanismo funcionalista são efetivamente descartados. Lamentavelmente, esses exemplos se concretizam em cidades europeias, na Austrália, em algumas cidades norte-americanas: longe daqui.

O quarto grupo de desenhos mostra duas imagens da cidade com gente. Porém, se trata de pessoas sós, transitando, circulando, silenciosas, indivíduos atomizados correndo atrás de suas próprias vidas, como se quem desenhasse fosse o próprio autor de "O homem da multidão" (Poe, 1840), narrando às ruas do centro de Londres em meados do século XIX. 

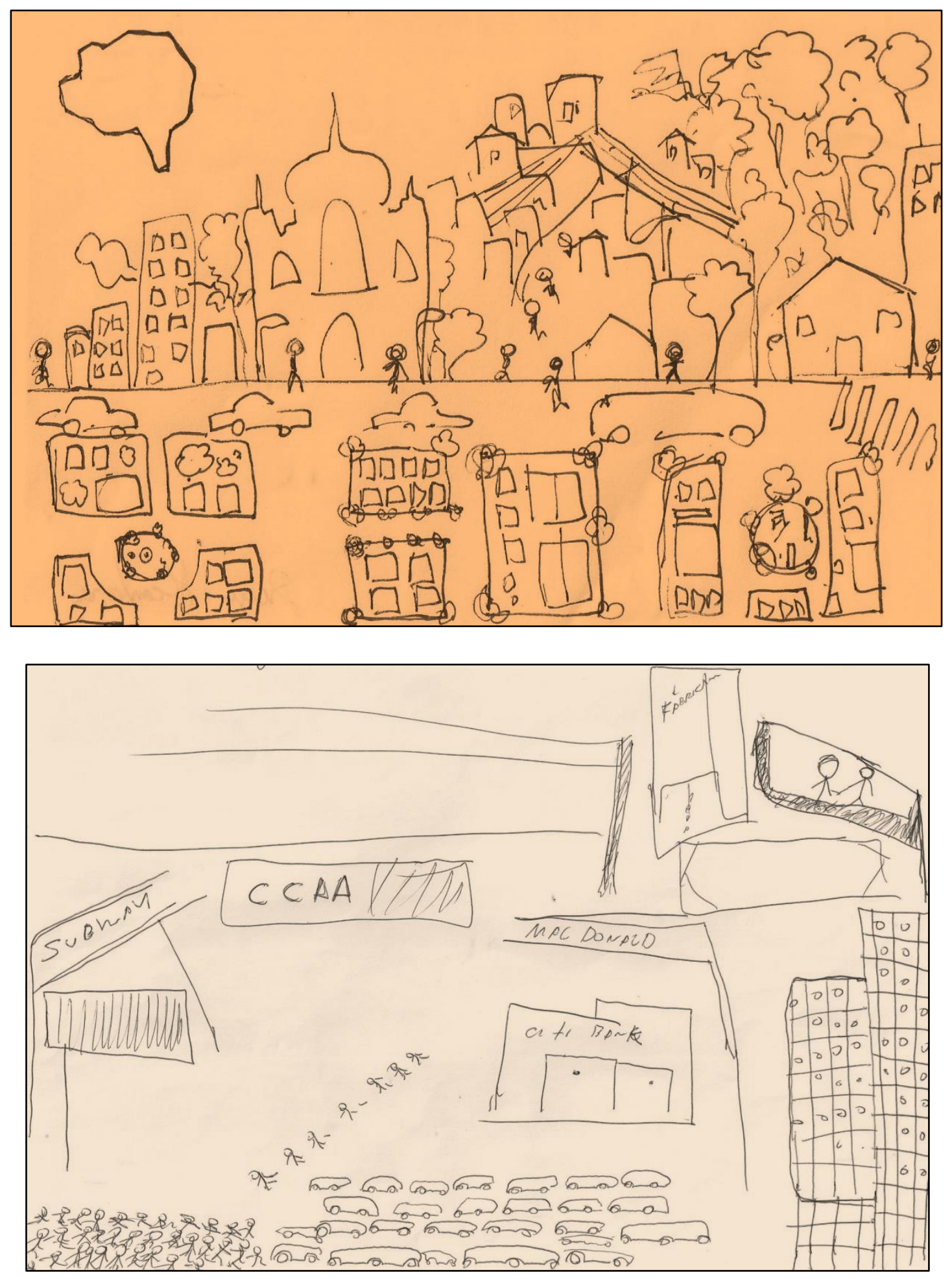
As cidades modernas são o palco de um fenômeno singular: o da solidão na multidão. É possível estar completamente só, apesar de estar constantemente rodeado de muitas pessoas nos ônibus, nas ruas, nos elevadores etc. Isso só é possível, escreveu Georg Simmel (1967), desenvolvendo uma atitude urbana particular: a atitude blasé. Em seu artigo A metrópole e a vida mental, escrito em 1902, Simmel relaciona tal atitude com a economia monetária e o seu predomínio do valor de troca, que gera um "embotamento do poder de discriminar": o homem blasé vê tudo ao seu redor como uniformemente plano, fosco, descolorido. Não se trata de uma perda da capacidade de distinguir, mas o surgimento de uma indiferença diante das diferenças, como reação racional de autopreservação. O homem blasé é um homem conscientemente indiferente, desinteressado, distanciado, reservado, cínico, um ser frio que sente repulsão pelo contato mais próximo com outrem.

Assim, quando as pessoas aparecem nos desenhos, aparecem como blasés, indiferentes a toda diferença, ensimesmadas, ao lado de muitas outras pessoas, porém sem vê-las.

No quinto bloco, a alteridade aparece em vários desenhos, mas se trata basicamente de uma alteridade espacial, da diferença-desigualdade entre formas de habitar e renda. As diferenças socioespaciais evidentes aparecem de forma clara nos desenhos a seguir. No primeiro, vemos a cidade dividida em quatro formas de habitar: uma onde a densidade impera (I), outra onde as pessoas são mortas (II), outra onde as árvores são mortas (III) e outra onde pessoas vivem, ou seja, riem (IV). As quatro formas de habitar correspondem às quatro áreas da cidade propostas por Inaiá Carvalho e Gilberto Pereira (2014): o centro, o subúrbio ferroviário, o miolo e o litoral norte, definidas em função do trabalho ou da ocupação da população economicamente ativa. Segundo esses autores,

o vetor Orla é predominantemente ocupado pelos tipos superiores e médiosuperiores, a área do centro tradicional, pelos tipos médios, e os vetores Subúrbio e Miolo, pelos tipos populares, configurando a fragmentação que Carvalho e Pereira (2008) denominaram como "cidade moderna, cidade tradicional e cidade precária" (Carvalho; Pereira, 2014: 59). 


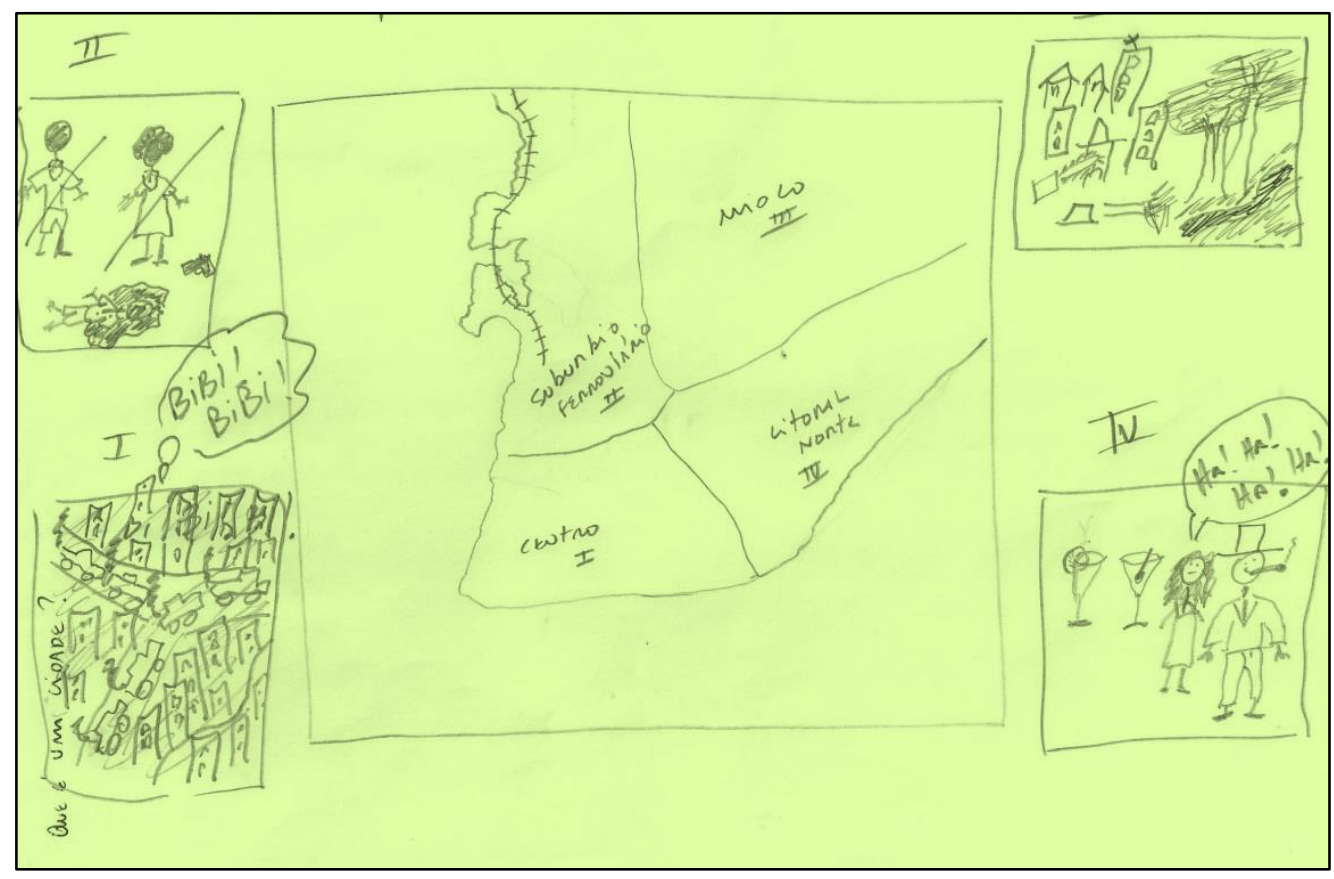

No desenho a seguir, elaborado um dia após as comemorações dos 450 anos da cidade do Rio de Janeiro, amplamente divulgadas pelas diferentes mídias, vemos que a desigualdade espacial não implica em distância espacial: formas desiguais de habitar e de renda estão lado a lado, são vizinhos. O conceito de justaposição ${ }^{6}$ corresponderia a este caso de proximidade espacial com uma enorme distância social (Vasconcelos, 2013).

\footnotetext{
${ }^{6}$ Justaposição me parece um termo mais correto do que segregação, pois este indica um isolamento forçado de comunidades homogêneas, um confinamento imposto de fora, tal qual a infligida aos guetos judeus ou aos bairros negros norte-americanos. Conforme conclui Pedro Vasconcelos (2013: 33), o termo segregação "aparece como uma palavra de ordem, ou como uma maneira de denunciar desigualdades sociais, mas com a perda de rigor e de precisão necessária para ser um instrumental analítico que ajude no avanço do conhecimento da realidade urbana".
} 


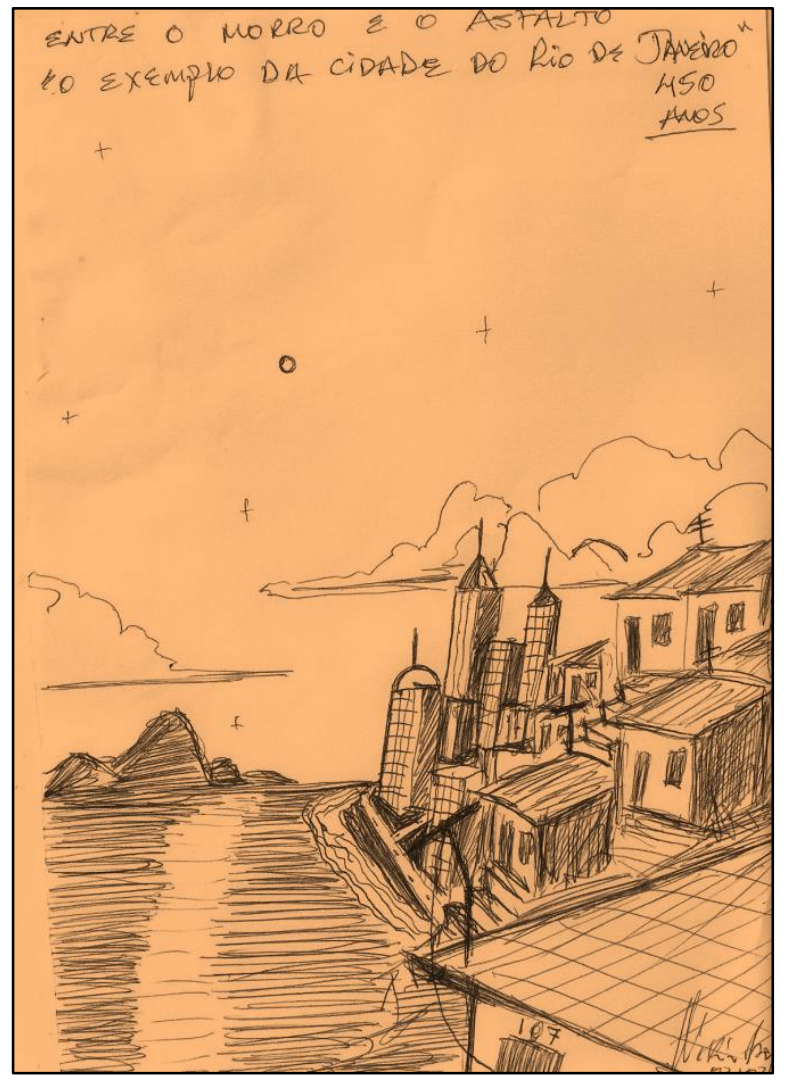

Encontramos a mesma justaposição na cidade de Salvador. Ao lado de bairros urbanizados e bem equipados em termos de serviços se erguem, geralmente em morros, bairros ou comunidades "populares", caracterizados por serem "espaços de ocupação aleatória, densos, deficientes de infraestrutura, portanto, em condições de habitabilidade precária" (Gordilho, 2008: 49).

A imagem de cidade nestes dois desenhos é a de uma unidade de opostos, uma proximidade de antagonismos, uma gritante desigualdade de setores, áreas ou bairros no interior dela.

No sexto e último bloco, a vida, a vizinhança, a cidade habitada por pessoas finalmente aparece. No primeiro, no entanto, ela seria privilégio de apenas uma parte da cidade: o morro. Só nele vemos pessoas interagindo e se divertindo, cantando, jogando bola. Enquanto isso, o resto dos habitantes fica atrás das paredes, no cimento, nas caixas, nos carros. 


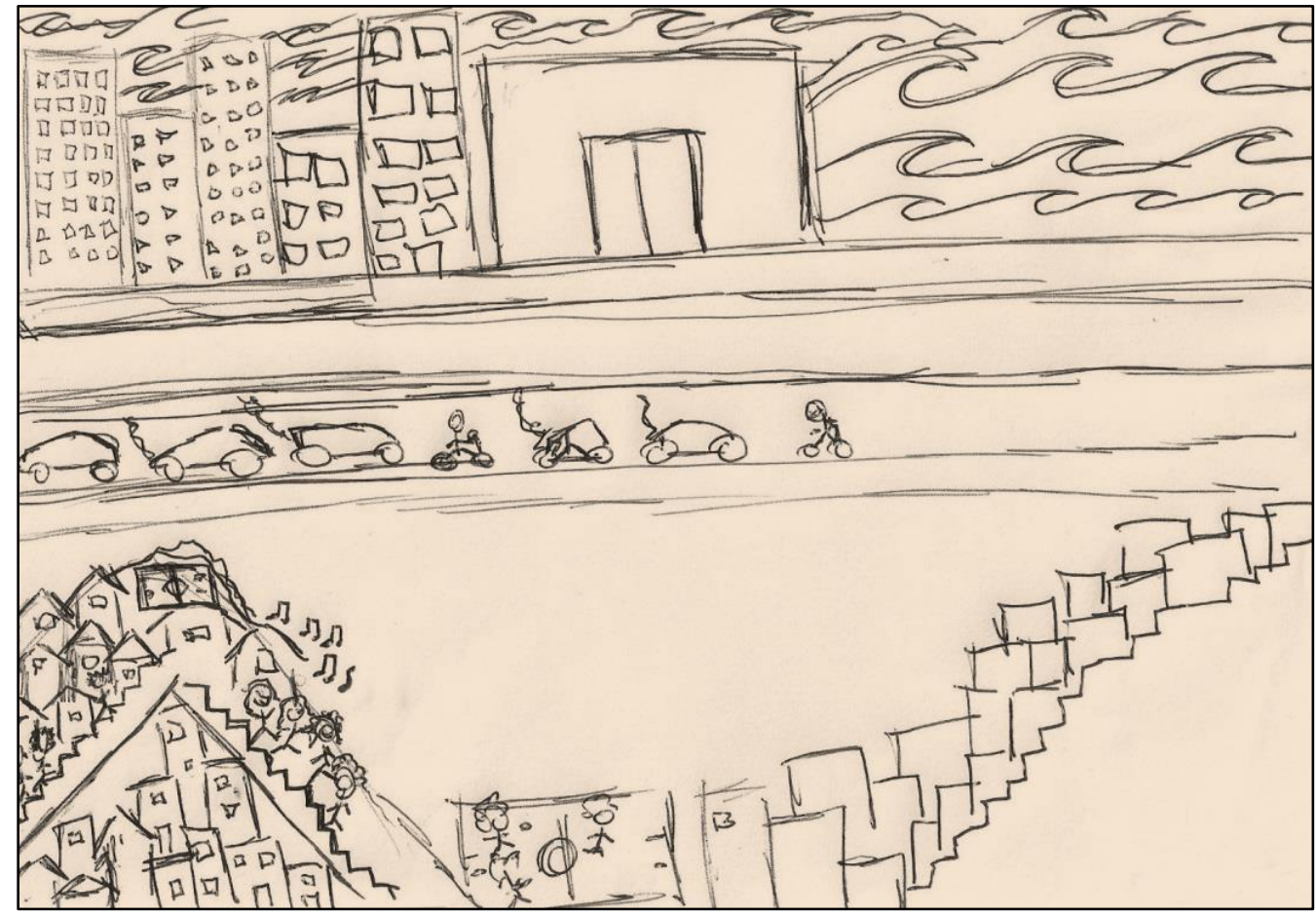

Este desenho me faz pensar o quanto a cidade partida, dual, polarizada, nutre uma imagem da cidade muito recorrente nos desenhos analisados. Com efeito, os conceitos dicotômicos têm ajudado importantes autores a pensar a realidade. Eis os casos dos conceitos de isotopia e heterotopia, propostos por Michel Foucault (1984) e Henri Lefebvre (2002), por exemplo. No entanto, para ambos os autores, um e outro conceito estavam profundamente imbrincados. Na visão de Foucault, as heterotopias são lugares onde se contesta e inverte o constituído (clínicas de repouso, prisões, cemitérios, museus, bibliotecas, feiras, bordéis, colônias, navios), sem, contudo, deixar de estar conectadas com as isotopias, servindo, assim, de ilusão ou compensação em relação aos espaços instituídos. Para Lefebvre, o Estado produz isotopias (espaços do igual) ao suprimir as diferenças no espaço, mediante leis, códigos, normas, mandamentos, preceitos, regras escritas em papéis que determinam previamente os usos do espaço. Os espaços que não interessam ao Estado são abandonados, transformados por seus habitantes em heterotopias (espaços da diferença). Mas, isotopias e heterotopias não são espaços claramente separados. As heterotopias se infiltram nas isotopias pelas próprias contradições que o capitalismo gera e as isotopias se infiltram nas heterotopias mediante as manobras do Estado para domesticar as diferenças (Montoya Uriarte, 2014). Assim, os conceitos são duais, mas não a realidade. 
Lamentavelmente, a visão polarizada da cidade resulta mais fácil de ser representada num desenho do que a dialética no e do espaço.

No seguinte desenho, a cidade habitada por pessoas não é privilégio de nenhum setor. A cidade é mais do que prédios e automóveis. A cidade são as pessoas, que não são robôs, que pensam, se perguntam, lembram, leem; há também música, amor, aviões e borboletas, árvores.

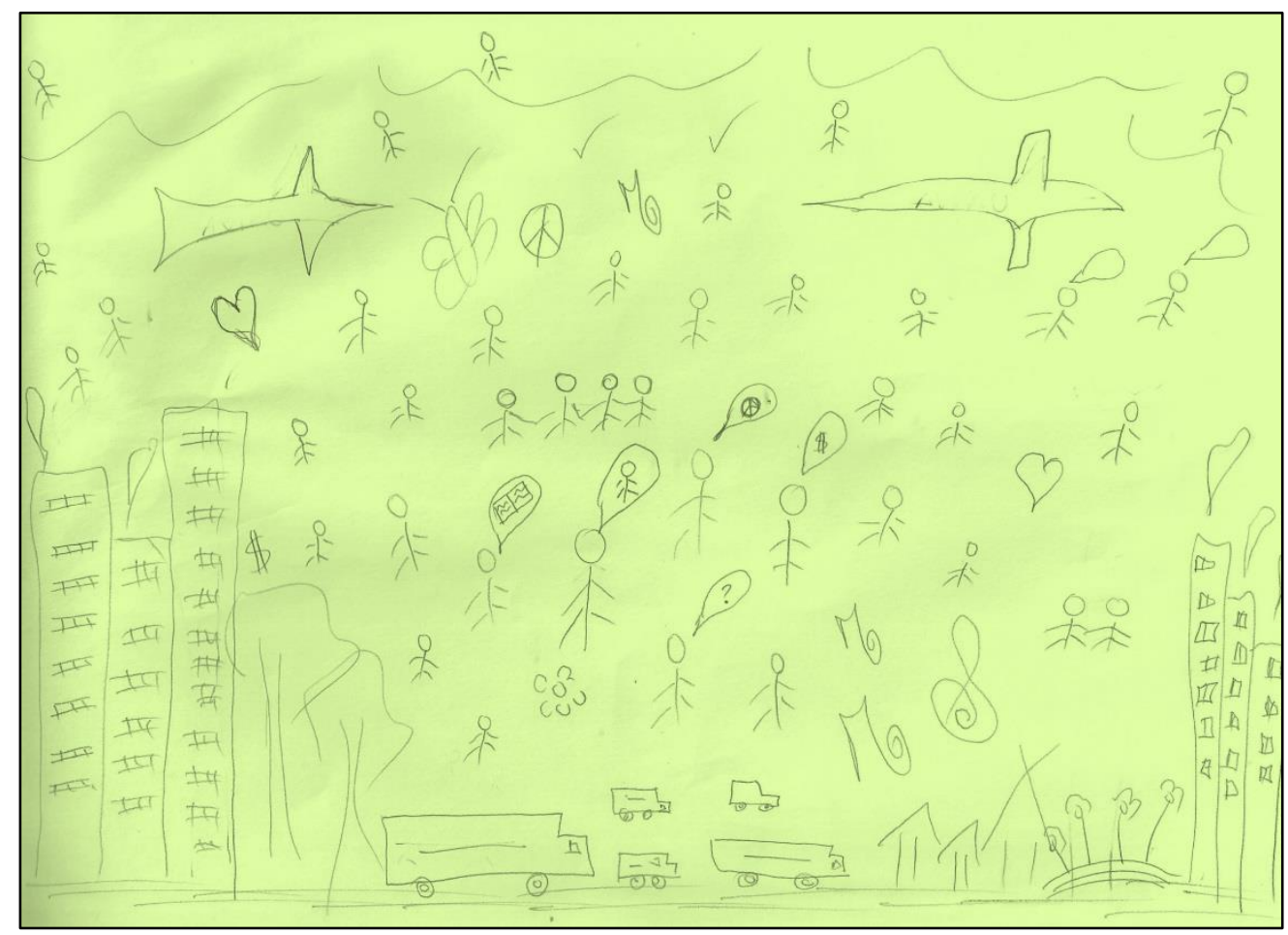

Nesse desenho, as pessoas estão literal e simbolicamente no centro da cidade. Cada uma delas é um mundo. A cidade-conjunto - sem síntese - transborda cores e sons, com os quais o desenhista parece manter uma grande intimidade. A cidade aparece nesse desenho como uma soma sem coerência final de uma multiplicidade de microcosmos (aviões, borboletas, pessoas) que convivem "desordenadamente", acumulando-se. A imagem que o desenho inscreve no papel pode bem ser o de uma cidade fenomenológica: “A cidade fenomenológica terá assim um caráter fragmentário, escenográfico e complexo, soma densa de peças que a experiência e o tempo foram destilando" (Ábalos, 2014: 102, tradução da autora). 
Este me parece ser o desenho que melhor plasma a diversidade que compõe e define a cidade enquanto realidade material que abriga uma abstração chamada por Lefebvre de "urbano": "o urbano é uma forma pura, o ponto de encontro, o lugar de uma reunião, a simultaneidade. Essa forma não tem nenhum conteúdo específico" (Lefebvre, 2002: 112). É bom lembrar, entretanto, que esta reunião inclui, também, o conflito. Ao lado de corações, portanto, poderiam também ter aparecido sinais de xingamentos, e, ao lado dos prédios, algumas prisões.

Já no desenho a seguir, a cidade habitada por pessoas aparece na imagem de uma cidade-rede, onde as conexões são feitas por cada habitante mediante as relações estabelecidas com indivíduos e lugares. A imagem da cidade corresponderia ao conjunto de relações indivíduos/lugares que acabam se conectando entre si.

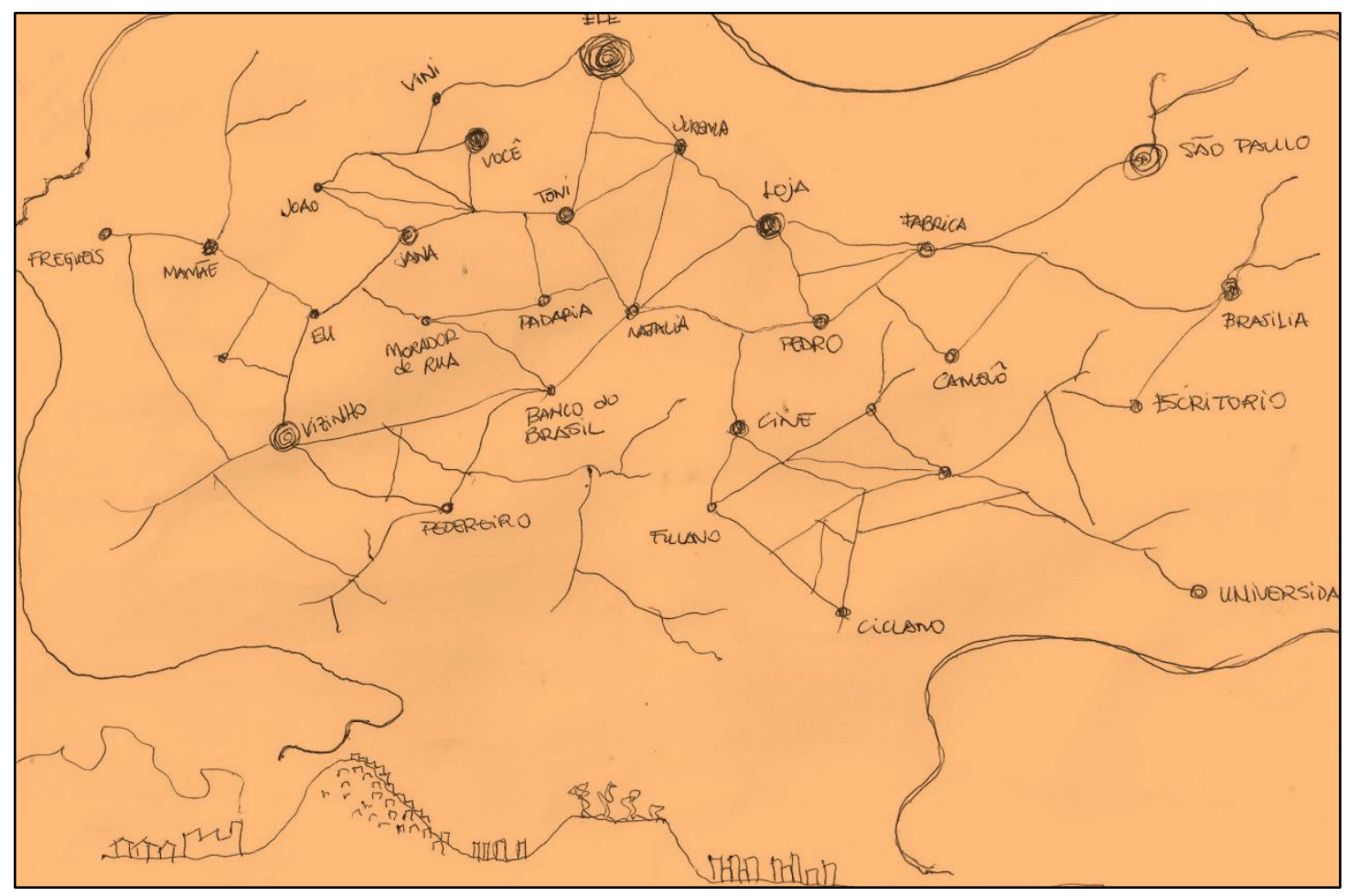

A chamada Escola de Manchester incorporou nos anos 1950 o conceito de rede em seu leque de categorias e sua agenda de pesquisa. $\mathrm{Na}$ antiga Rodésia, os antropólogos do Rhodes-Livingstone Institut inovaram metodologicamente, propondo estudos de caso, casos ampliados e análises situacionais que, por sua vez, levaram esses pesquisadores a proporem o conceito de rede como forma de falar de atributos relacionais e de formas mediante as quais os vínculos se ajustam uns aos outros (Hannerz, 1980). Falou-se em redes para descrever as conexões entre indivíduos, os 
quais ultrapassavam os contornos de grupos definidos ${ }^{7}$. Na atualidade, Michel Agier (2011) retoma o legado da Escola de Manchester e a importância conferida às redes para descrever as cidades. Segundo ele, os tipos de redes existentes numa cidade podem colocar em evidência os papéis sociais exercidos nela ${ }^{8}$.

No desenho, tal qual a teoria e os estudos empíricos da Escola de Manchester e de Agier, a imagem da cidade corresponde a uma multiplicidade de contatos, a relações entre relações, a uma abrangência das inter-relações entre pessoas e pessoas e lugares na cidade.

Cada um dos desenhos reproduzidos até aqui nos seis blocos enfatiza, portanto, um aspecto da cidade: a compartimentalização de atividades; o vazio dos espaços públicos; a sensação de insegurança permanente dos indivíduos que vivem nela; a percepção de o quanto as pessoas são ignoradas em favor dos automóveis; os indivíduos atomizados, indiferentes diante das diferenças; a proximidade dos antagonismos e a gritante desigualdade entre seus espaços internos; a dualidade de formas de habitar; a ampla rede de relações; a reunião da diversidade representada por pessoas heterogêneas.

As imagens são bastante realistas. Falam, eu acredito, dos aspectos que mais marcam a vida urbana de cada um dos que a desenharam. A totalidade da cidade ou da vida urbana, assim, não aparece. E nem poderia. Primeiro, por uma impossibilidade perceptiva: "nossa percepção da cidade não é abrangente, mas antes parcial, fragmentária, misturada com considerações de outra natureza”, advertia Lynch (1997: 2). Segundo, porque os percursos efetuados por cada citadino necessariamente fragmentam a cidade vivida por eles. É precisamente sobre a importância dos percursos que falaremos na seção a seguir.

\footnotetext{
${ }^{7}$ Num artigo escrito em 1954, J. A. Barnes propunha entender as redes como "um conjunto de pontos, alguns dos quais estão unidos por linhas. Os pontos das imagens são pessoas, às vezes grupos, e as linhas indicam quais as pessoas que interagem entre si" (Barnes apud Mayer, 2009: 144). Em 1969, ele definiu a rede como "um conjunto de relações interpessoais concretas que vinculam indivíduos a outros indivíduos" (Barnes, 2009: 180).

${ }^{8}$ Foi o que ele concluiu em seu estudo das redes no bairro da Liberdade, em Salvador. As redes masculinas - familiares, da vizinhança, para o lazer, relativamente fechadas - e as redes femininas - mais abertas e mais dispersas - lhe permitiram visualizar atitudes urbanas "mais abertas e centrífugas para as mulheres, mais fechadas e localizadas para os homens" (Agier, 2011: 86) e deduzir os papéis diferenciados entre ambos os gêneros: "É o papel doméstico e mediador das mulheres, na organização familiar, que explica um papel urbano marcado pelas busca de soluções de sobrevivência econômica e pela ativação de redes abertas: 'é preciso se dar bem com todo mundo' é uma das advertências mais ouvidas nas casas das mulheres de bairro" (idem).
} 


\section{Imagens e experiências: a importância dos percursos cotidianos na imagem da cidade}

As imagens não são verdadeiras ou falsas, nem aleatórias. As imagens que temos da cidade podem advir do que vemos nas telas do cinema, das imagens transmitidas pelos noticiários da televisão ou das imagens-clichês da publicidade. Essas imagens se justapõem com outras, de outro tipo, que são as imagens produzidas pelas experiências vividas por cada pessoa, lembradas. Essas imagens estão interiorizadas e foram elas as que quis atingir quando solicitei "desenhem a cidade".

Essas imagens são uma forma de saber, um saber condensado em formas. Seguindo Maurice Merleau-Ponty (1971), acredito que todo saber advém das experiências: "tudo o que sei do mundo, mesmo devido à ciência, o sei a partir de minha visão pessoal ou de uma experiência do mundo sem a qual os símbolos da ciência nada significariam" (Merleau-Ponty, 1971: 6). Assim, mais do que expressar uma realidade exterior ou ser uma representação que permite a leitura da realidade, as imagens expressam, a meu ver, as experiências urbanas vividas (corporal e sensivelmente) pelos seus autores. Influenciada por este autor, compreendo a experiência como uma “abertura ao nosso mundo de fato" (Merleau-Ponty, 1971: 227), como uma atitude ativa (não passiva), um estar no mundo.

Afirmo, pois, que as imagens que os alunos desenharam advêm basicamente de suas experiências urbanas, dentre as quais uma é extremamente significativa: os percursos cotidianos. Esta afirmação se consolidou quando, revisando o conjunto de desenhos da turma de 2013.1, encontrei uma pasta que reunia cartografias dos trajetos cotidianos de cada aluno, feitos no final do semestre, após lermos e discutirmos a seção "Práticas de espaço" do livro A Invenção do cotidiano I, de Michel de Certeau (2009), dedicado aos percursos. Este segundo tipo de desenhos é o fruto de um exercício gráfico feito em casa, com bastante tempo disponível, no qual tinham de cartografar seus trajetos, devidamente alertados da necessidade de não deixar de fora o papel das emoções e interações neles. O resultado foi um conjunto bastante interessante de desenhos que, se colocados ao lado dos desenhos solicitados no início do semestre, nos ajudam a entender o porquê das imagens da cidade plasmadas no papel. 
Vejamos apenas três casos para não nos estendermos demais. No primeiro caso, temos um trajeto que começa no elegante bairro do Horto Florestal (Chácara Inglesa) e vai até São Lázaro (Federação), onde se localiza a Faculdade de Filosofia e Ciências Humanas. O desenho não explicita interações, incomodidades, cheiros, deslumbramentos, surpresas.

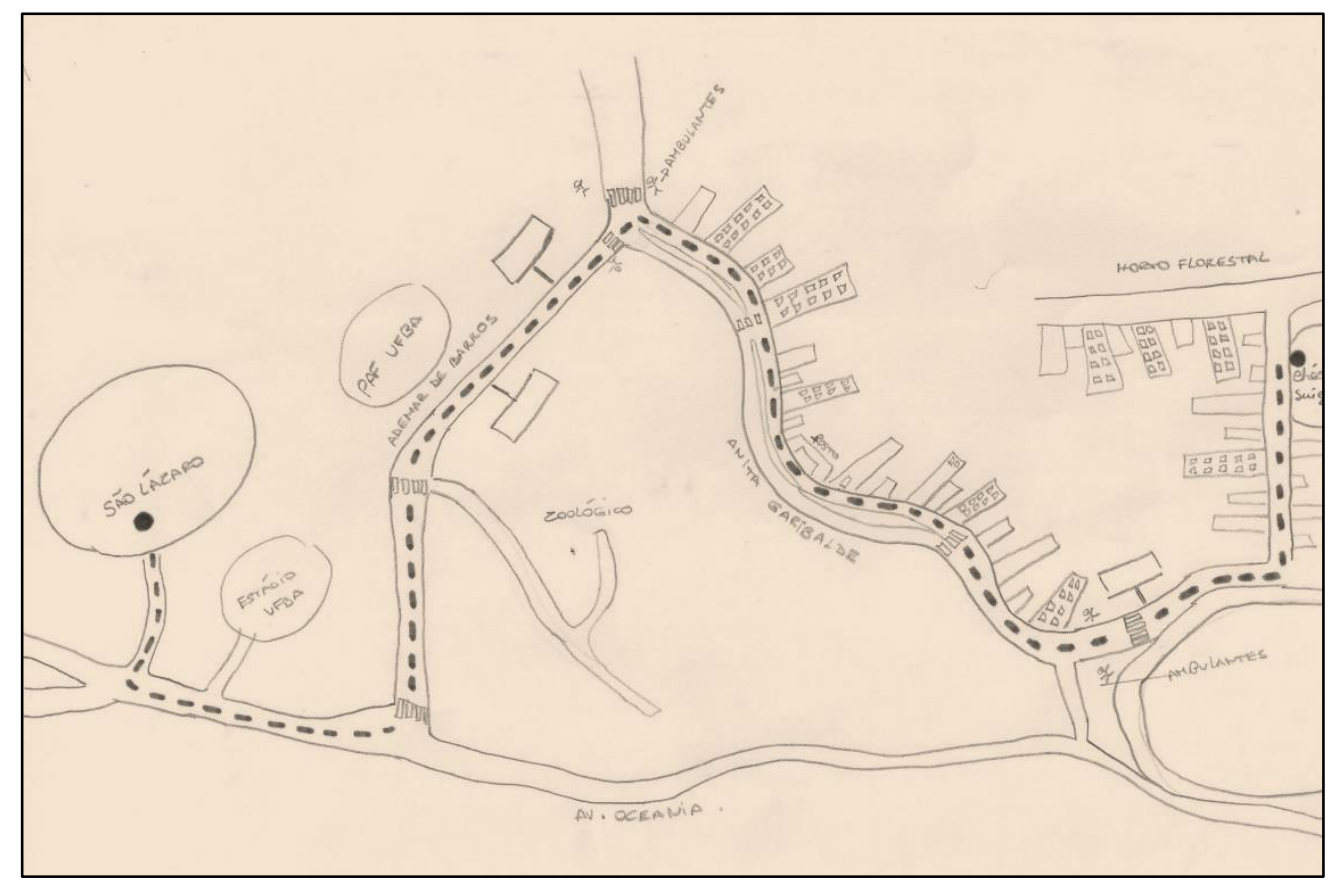

O trajeto cotidiano é feito de carro, pois não há menção a paradas, a esperas, a confusão de gente, além da entrada escolhida para ingressar em São Lázaro ser uma que não tem acesso a ônibus. Trata-se de um trajeto contínuo através de ruas largas e avenidas. Grande parte dele percorre uma avenida de vale ${ }^{9}$ - a Avenida Garibaldi -, cuja paisagem, para o autor, é de prédios.

Vejamos agora o que este aluno desenhou no exercício do primeiro dia de aula. A imagem desenhada foi de avenidas, prédios, muitos carros, pouquíssimas pessoas. As mesmas características que aparecem no desenho de seu percurso diário.

\footnotetext{
${ }^{9}$ Salvador é uma cidade que nasceu na parte superior das colinas. A parte baixa, inicialmente, não era habitada devido aos alagamentos que se formavam pelas fortes chuvas. No século XX, mais especificamente na década de 1970, muitos vales da cidade foram transformados em vias amplas de trânsito, que contrastam com as vias estreitas e tortuosas da parte média e de cima das colinas.
} 


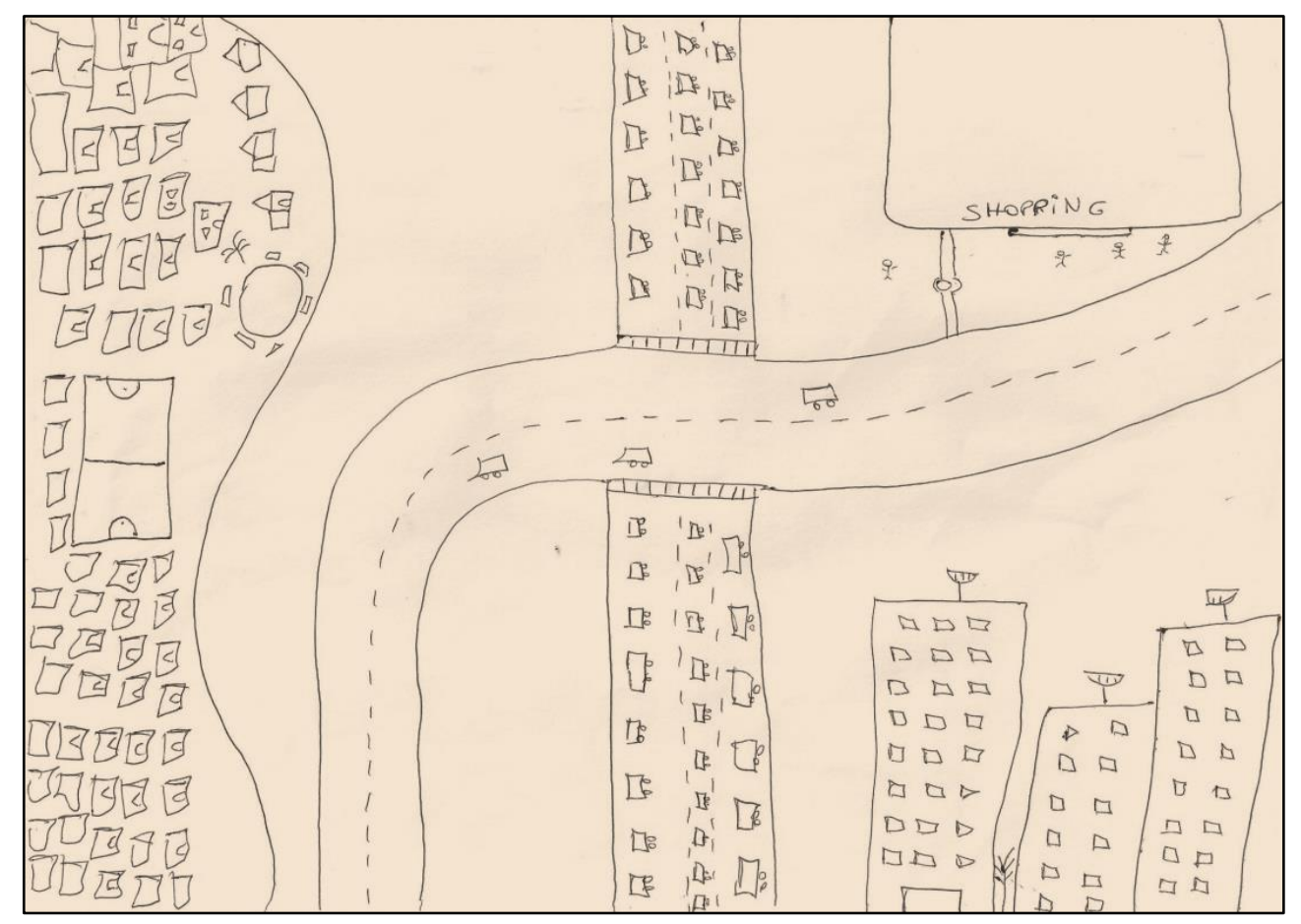

Na segunda dupla de desenhos vemos incialmente um trajeto cotidiano feito por diversos tipos de ruas e de ônibus. Na parte superior do desenho, o aluno usou símbolos para expressar um longo trajeto composto por vias circulares, retornos, vias retas, viradas etc. Na parte do meio, o aluno desenhou alguns momentos desse trajeto: o ponto de ônibus, o ônibus, a passagem pelo cemitério, o momento intimista dentro do ônibus, e a caminhada final por uma rua margeada de árvores e prédios até chegar a São Lázaro. $\mathrm{Na}$ parte inferior do desenho, ele escreve o que sente ao longo de seu trajeto ("correria, ansiedade, stress, angústia, estratégia, satisfação, expectativas, esperanças, lembranças, reflexões”). Em seu trajeto não há interações com outras pessoas. É um trajeto intimista. 


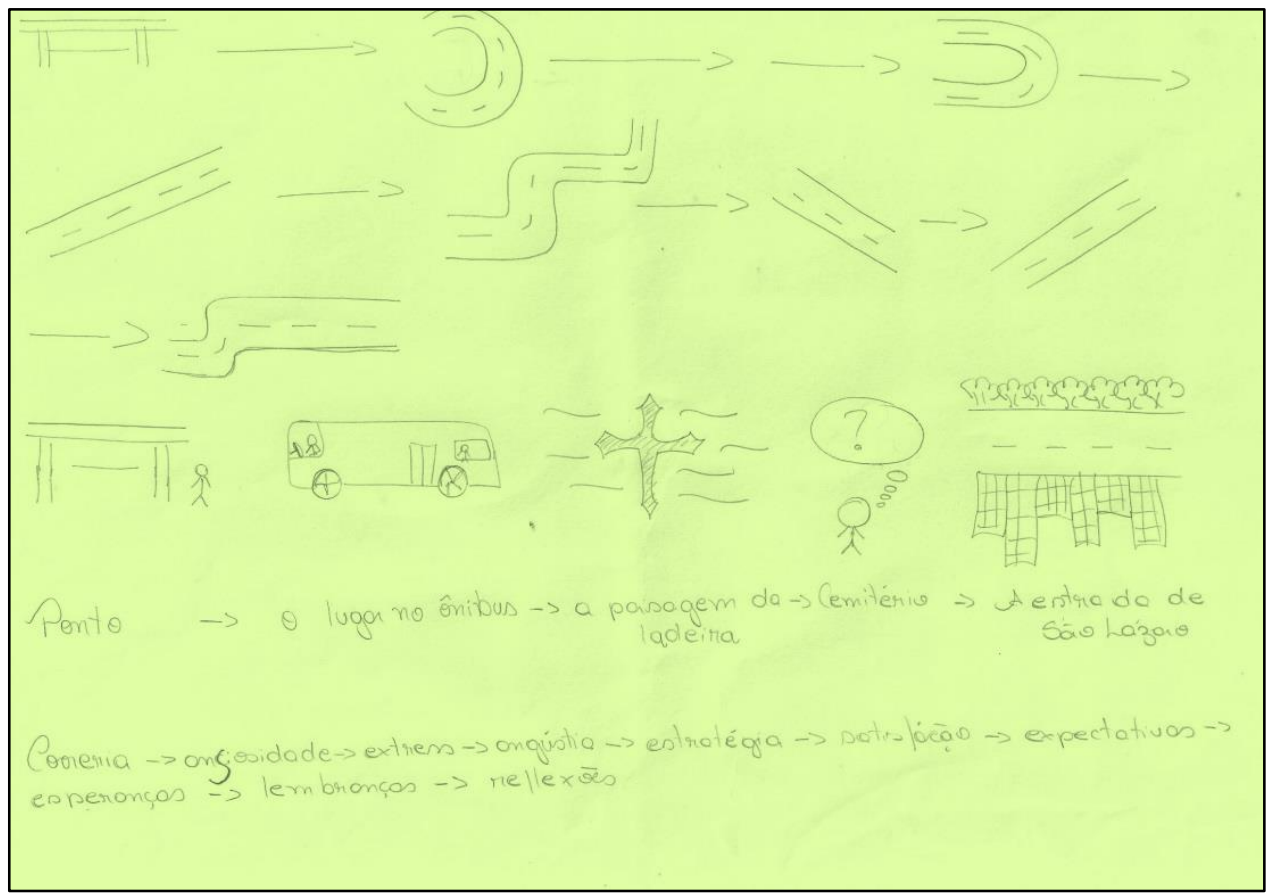

No primeiro exercício, a imagem de cidade que foi plasmada foi uma de muitas vias que conectam os bairros periféricos com a área central da cidade. As vias podem ser ora retas ora curvas, como as que ele atravessa em seu trajeto cotidiano. $\mathrm{Na}$ imagem de cidade que ele desenha, assim como em seu trajeto, não há interações.

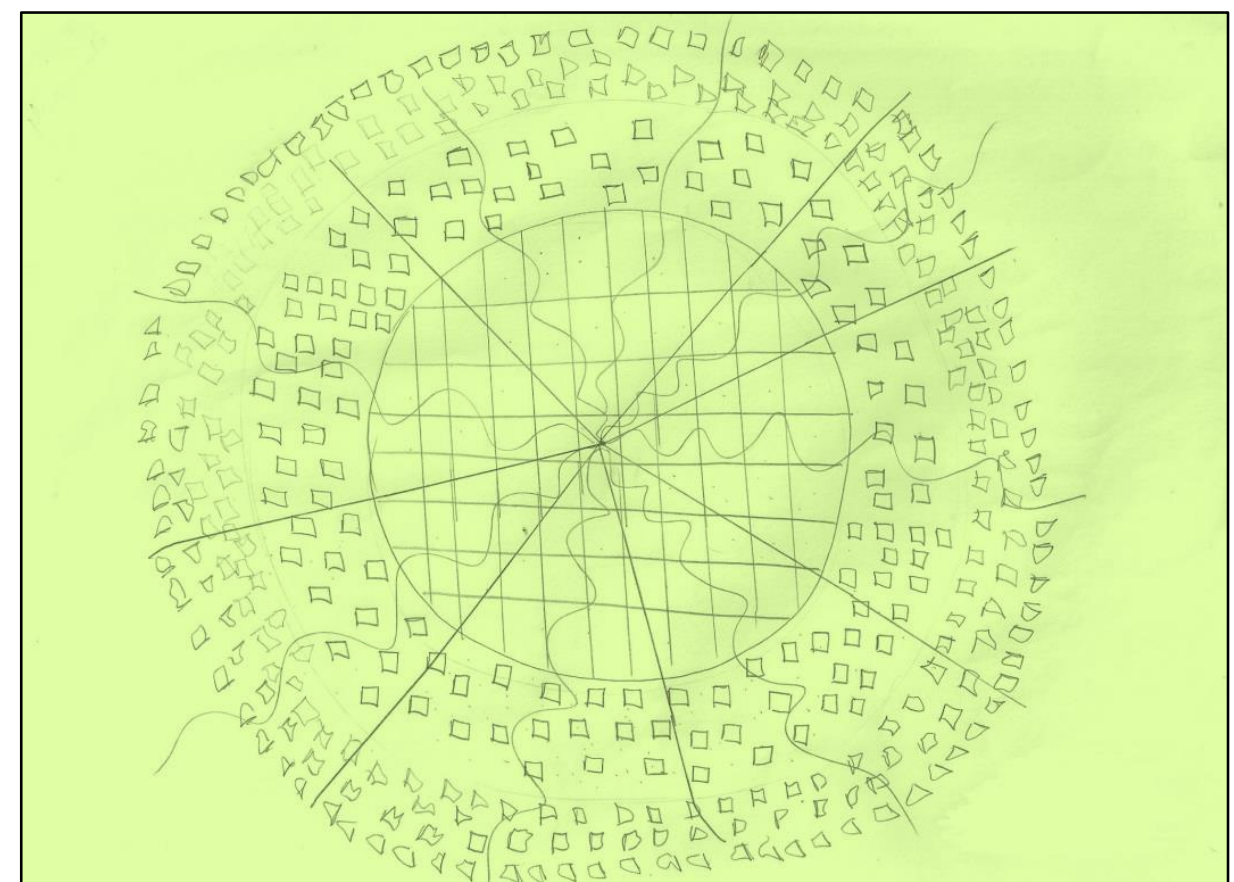


Finalmente, no terceiro caso, vemos um trajeto cotidiano feito num ônibus lotado, no qual o autor não consegue sentar, passando por lugares muito movimentados e cheios de gente (a estação de transbordo do Iguatemi, a avenida Antônio Carlos Magalhães), com prédios e barulho. Quando passa pelo bairro costeiro do Rio Vermelho, ele se sente tranquilizado pelo mar. Na Federação (avenida Cardeal da Silva), de novo, muita gente. O ônibus está sempre lotado. Na Estrada de São Lázaro, que percorre a pé para chegar à faculdade, vê gente andando como ele e pessoas passeando seus cachorros (o aluno anterior só via vegetação e prédios nessa mesma rua). O desenho que ele fez da cidade não poderia ser mais explícito de sua experiência urbana cotidiana, de seus trajetos: um espaço cheio de gente.

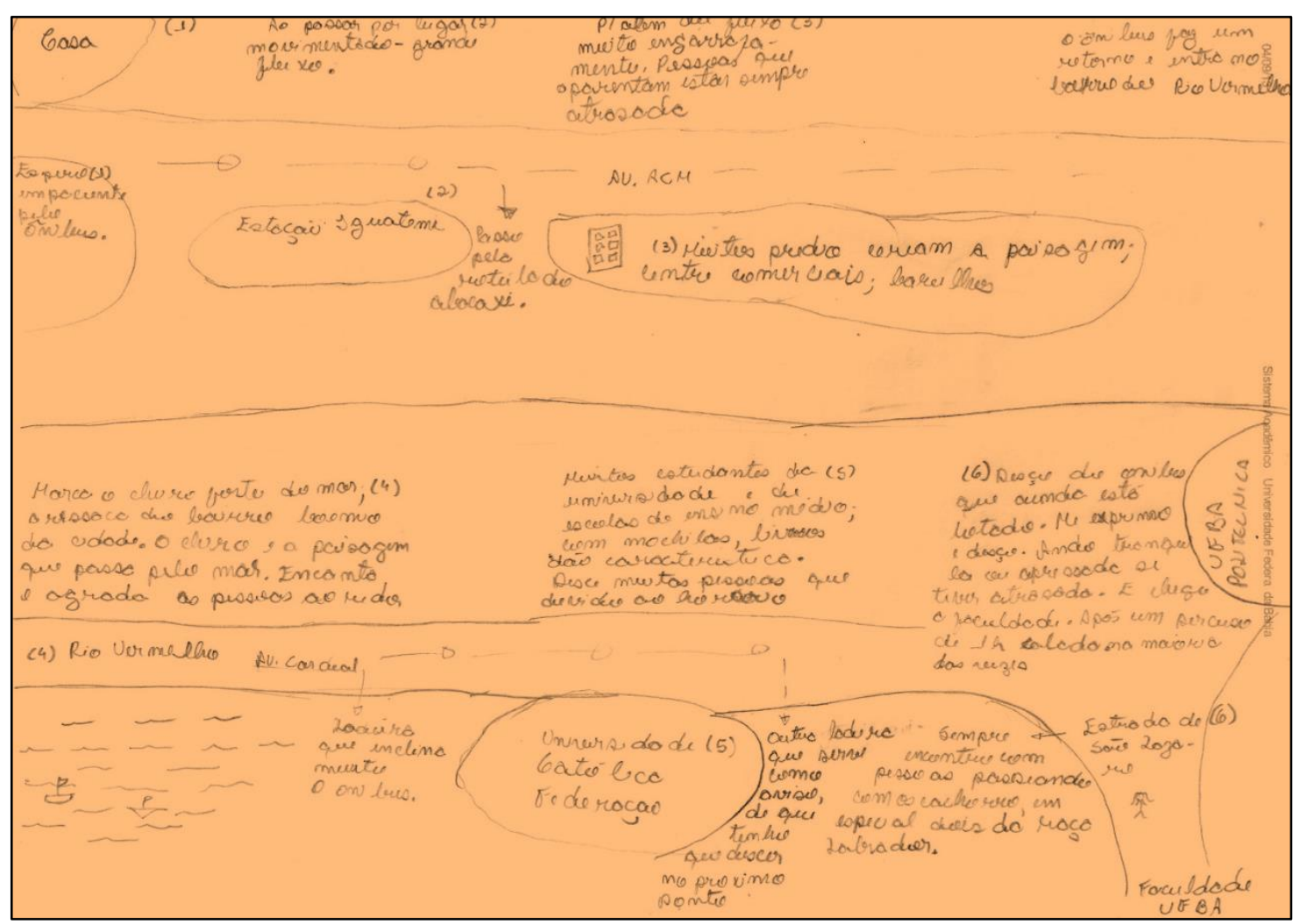




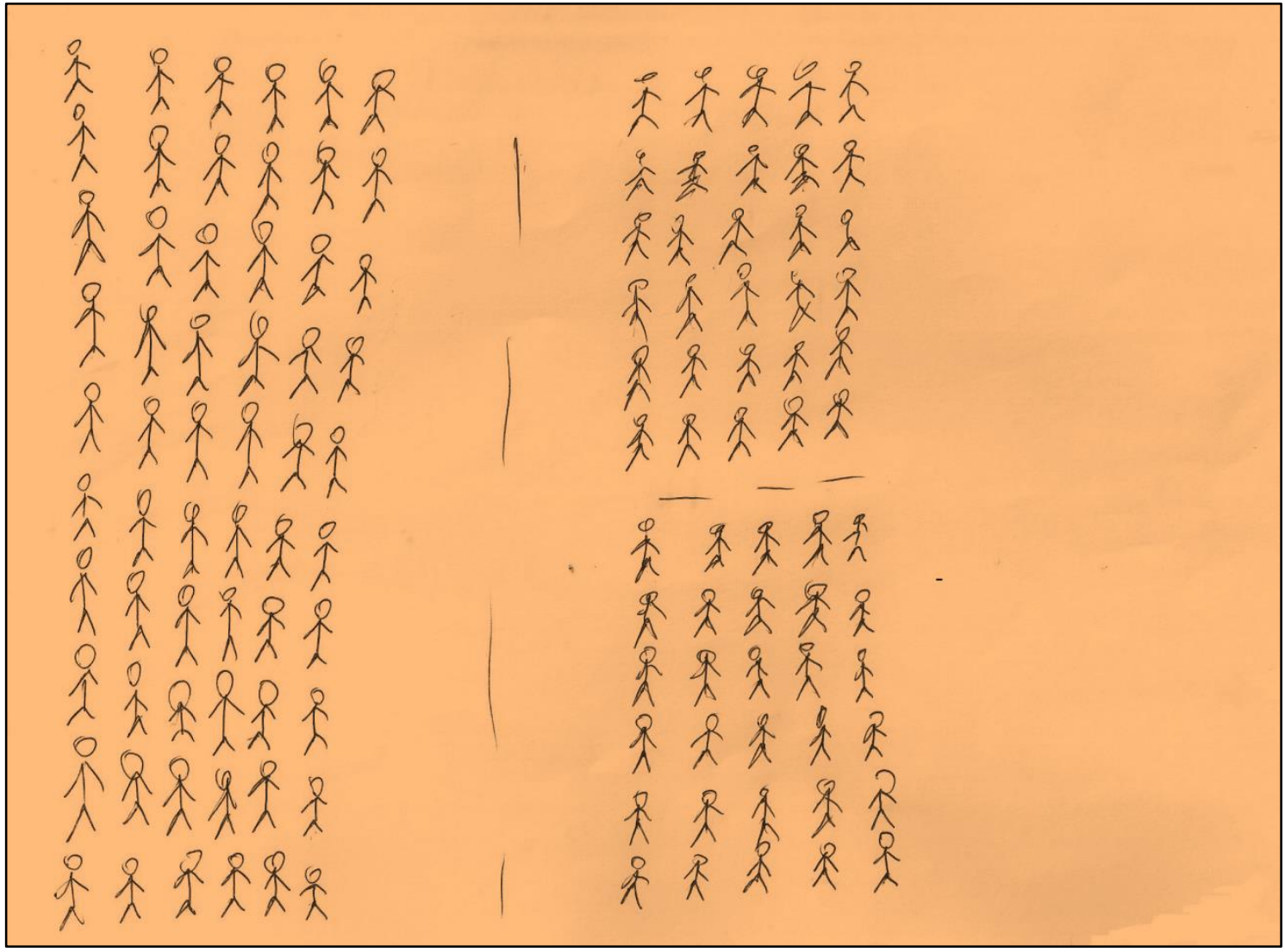

Estas três duplas de desenhos nos mostram de forma bastante evidente o quanto as experiências (no caso, a dos trajetos cotidianos) que os urbanitas têm nutrem as imagens que os mesmos constroem da cidade.

\section{Palavras finais sobre as imagens de cidade sem gente}

Os desenhos apresentados na primeira seção deste artigo mostram diversas imagens da cidade que, apesar de enfatizarem aspectos diferentes da realidade urbana, partilham - com exceção dos desenhos do bloco 6 - um aspecto: trata-se de imagens de cidade sem gente. Na grande maioria dos desenhos, as ruas aparecem vazias, as praças desocupadas, os citadinos aparentam se esconder em suas casas, prédios ou trabalhos, o concreto parece engolir as pessoas, os carros substituem os homens e mulheres. Essas imagens parecem nos dizer o quanto a alteridade não é mais fator importante na definição de cidade, pois a ordem, o abandono do público e o medo produzem uma cidade que não oferece saídas, que gera angústias, que retrai e promove a indiferença. Quando as pessoas aparecem nos desenhos, se trata de pessoas ensimesmadas, 
indiferentes umas às outras, blasés. As pessoas enquanto seres sociais surgem apenas nos últimos três desenhos.

Em dois dos três trajetos analisados vimos que as experiências que nutrem as imagens da cidade são experiências sem interações com pessoas. No carro ou no ônibus, as pessoas vistas não provocam os sentidos, não aguçam o interesse, não demandam do desenhista uma relação, um diálogo, uma comunicação. Em oura ocasião, admiti o quanto é difícil ver a cidade: a rotina automatiza a percepção, a velocidade provoca um achatamento da paisagem, o resultado é que acabamos vendo apenas aquilo que nos interessa ver (Montoya Uriarte, 2013). Assim, as pessoas, apesar de serem vistas, não são consideradas como um componente essencial da imagem que se tem das cidades.

Esta conclusão - se é que podemos falar em conclusões a partir do escasso material que trabalhamos - me parece alarmante. Em primeiro lugar, porque o elemento central de qualquer visão minimamente antropológica - urbana ou não - é, ou deveria ser, as pessoas. Afinal, ao longo de vários semestres, os alunos aprendem que a Antropologia é "uma filosofia com gente dentro" (Ingold, 2008), uma disciplina que estuda pessoas, ou, mais corretamente, com as pessoas, para as pessoas. Em segundo lugar, me parece alarmante não ver que a cidade é produzida não apenas por um modo de produção dominante ou pela herança de outros tempos, mas, principalmente, por pessoas. Elas são agentes centrais da produção da cidade. Cada ponto de ônibus, cada passarela de pedestres, cada caminho traçado, cada praça, cada esquina, cada canto é um campo de tensão de forças do Estado, do tempo e dos homens enquanto usuários, moradores, consumidores, fregueses, vizinhos ou outras formas de ser citadino. Dentre os homens produtores da cidade, destaco os "homens ordinários", que, para sobreviver, precisam fraturar o espaço, fazer caber nele diferenças não previstas, particularidades não calculadas, produzindo, assim, outros espaços mediante apropriações, desvios, contornos etc. (Montoya Uriarte, 2014).

Acho que a etnografia, ou, ao menos, o espírito etnográfico, há de jogar um papel decisivo para aprender a ver a cidade de pessoas, para restituir às pessoas o lugar de destaque que elas têm na cidade, pois o método etnográfico se funda precisamente no estabelecimento de relações com as pessoas, no engajamento e no convívio prolongados com elas, na necessidade de ocupar um lugar no sistema dessas pessoas, no respeito pelo conhecimento delas e na produção de um conhecimento com elas (Montoya Uriarte, 2012). 


\section{Referências}

ÁBALOS, Iñaki. La buena vida. Visita guiada a las casas de la modernidade. Barcelona: Gustavo Gili, 2014.

ABRAHÃO, Sérgio Luís. Espaço público: do urbano ao político. São Paulo: Annablume; Fapesp, 2008.

AGIER, Michel. Antropologia da cidade: lugares, situações, movimentos. São Paulo: Terceiro Nome, 2011.

BARNES, J. A. Redes sociais e processo político. In: FELDMAN-BIANCO, Bela (org.). Antropologia das sociedades contemporâneas. Métodos. São Paulo: Unesp, p. +, 2009.

BAUMAN, Zygmunt. Confiança e medo na cidade. Rio de Janeiro: Zahar, 2009.

CARVALHO, Inaiá; PEREIRA, Gilberto. Salvador como negócio. In:

Metrópoles na atualidade brasileira. Transformações, tensões e desafios na Região Metropolitana de Salvador. Salvador: Edufba, 2014.

CERTEAU, Michel de. A invenção do cotidiano 1. Artes de fazer. Petrópolis: Vozes, 2009.

DO RIO, João. A alma encantadora das ruas. São Paulo: Companhia das Letras, 2008.

FOUCAULT, Michel. De outros espaços. Conferência proferida no Cercle d'Études Architecturales, 14 de março de 1967. Architecture, Mouvement, Continuité, n. 5, p. 46-49, out. 1984. Disponível em: <http:// analobocrispi.files.wordpress.com/.../michelfoucaultheterot_carmela.pdf $>$. Acesso em: 28/03/2015.

GHEL, Jan. Cidades para pessoas. 2. ed. São Paulo: Perspectiva, 2013.

GORDILHO, Ângela. Limites do habitar. Segregação e exclusão na configuração urbana contemporânea de Salvador e perspectivas no final do século XX. 2. ed. revista e ampliada. Salvador: Edufba, 2008.

HANNERZ, Ulf. Exploración de la ciudad. Hacia una antropología urbana. México: Fondo de Cultura Económica, 1980.

INGOLD, Tim. Anthropology is not ethnography. British Academy, n. 154, p. 69-92, 2008. Disponível em: 〈http://proc.britac.ac.uk/files/154p069.pdf>. Acesso em: 30/08/2014.

JACOBS, Jane. Muerte y vida de las grandes ciudades. Madri: Península, 1973.

JOLY, Martine. Introdução à análise da imagem. Campinas: Papirus, 1994.

LE CORBUSIER. La ciudad del futuro. Buenos Aires: Infinito, 1962.

LEFEBVRE, Henri. A revolução urbana. Belo Horizonte: UFMG, 2002.

LYNCH, Kevin. A imagem da cidade. São Paulo: Martins Fontes, 1997.

MAYER, Adrian C. A importância dos quase grupos no estudo das sociedades complexas. In: FELDMAN-BIANCO, Bela (org.). Antropologia das sociedades contemporâneas. Métodos. São Paulo: Unesp, 2009.

MERLEAU-PONTY, Maurice. Fenomenologia da percepção. Rio de Janeiro, São Paulo: Livraria Freitas Bastos, 1971.

MONTOYA URIARTE, Urpi. O que é etnografia para os antropólogos. Ponto Urbe, n. 11, dez. 2012. Disponível em: <http://www.pontourbe.net/edicao11-artigos/248-o-que-e-fazeretnografia-para-os-antropologos>. Acesso em: 27/03/2014.

. Olhar a cidade. Contribuições para a etnografia dos espaços urbanos. Ponto Urbe, n. 13, dez. 2013. Disponível em: <http://www.pontourbe.net>. Acesso em: 11/10/2014.

. A produção do espaço urbano pelos homens ordinários. Antropologia de dois microespaços na cidade de Salvador. Revista Iluminuras, v. 15, n. 36, p. 115-134, ago./dez. 2014. Disponível em: <http://seer.ufrgs.br/index.php/iluminuras/article/view/52637/32585>. Acesso em: 30/07/2015.

POE, Edgard Alan. $O$ homem da multidão. Londres, 1840. Disponível em: <http://www.ufrgs.br/proin/versao_2/textos/homem.rtf>. Acesso em: 30/07/2015.

ROLNIK, Raquel. O que é cidade? São Paulo: Brasiliense, 1988.

SENNETT, Richard. The uses of disorder. Personal identity and city life. Nova York: Alfred A. Knopf, 1970.

O declínio do homem público. As tiranias da intimidade. São Paulo: Companhia das 
Letras, 1988.

SIMMEL, Georg. A metrópole e a vida mental. In: VELHO, Otávio (org.). O fenômeno urbano. Rio de Janeiro: Jorge Zahar, 1967.

VASCONCELOS, Pedro. Contribuições para o debate sobre processos e formas socioespaciais nas cidades. In: et al. A cidade contemporânea. Segregação espacial. São Paulo: Contratexto, 2013.

Recebido em: 30/05/2017. Aprovado em: 01/08/2017. 